\title{
Impact of Mexico City emissions on regional air quality from MOZART-4 simulations
}

\author{
L. K. Emmons ${ }^{1}$, E. C. Apel ${ }^{1}$, J.-F. Lamarque ${ }^{1}$, P. G. Hess ${ }^{1, *}$, M. Avery $^{2}$, D. Blake ${ }^{3}$, W. Brune ${ }^{4}$, T. Campos ${ }^{1}$, \\ J. Crawford ${ }^{2}$, P. F. DeCarlo ${ }^{5}$,* , S. Hall ${ }^{1}$, B. Heikes ${ }^{6}$, J. Holloway ${ }^{7}$, J. L. Jimenez ${ }^{5}$, D. J. Knapp ${ }^{1}$, G. Kok ${ }^{8}$, \\ M. Mena-Carrasco ${ }^{9, * * *}$, J. Olson ${ }^{2}$, D. O'Sullivan ${ }^{10}$, G. Sachse ${ }^{2}$, J. Walega ${ }^{1}$, P. Weibring ${ }^{1}$, A. Weinheimer ${ }^{1}$, and \\ C. Wiedinmyer ${ }^{1}$ \\ ${ }^{1}$ National Center for Atmospheric Research, Boulder, CO, USA \\ ${ }^{2}$ NASA Langley Research Center, Hampton, VA, USA \\ ${ }^{3}$ Department of Chemistry, University of California, Irvine, CA, USA \\ ${ }^{4}$ Department of Meteorology, Pennsylvania State University, University Park, PA, USA \\ ${ }^{5}$ Department of Chemistry and Biochemistry, University of Colorado, Boulder, CO, USA \\ ${ }^{6}$ Graduate School of Oceanography, University of Rhode Island, Narragansett, RI, USA \\ ${ }^{7}$ NOAA, Earth System Research Laboratory, Boulder, CO, USA and Cooperative Institute for Research in Environmental \\ Science, University of Colorado, Boulder, CO, USA \\ ${ }^{8}$ Droplet Measurement Technologies, Boulder, CO, USA \\ ${ }^{9}$ University of Iowa, USA \\ ${ }^{10}$ Chemistry Department, US Naval Academy, Annapolis, MD, USA \\ * now at: Department of Biological and Environmental Engineering, Cornell University, Ithaca, NY, USA \\ ** now at: Laboratory of Atmospheric Chemistry, Paul Scherrer Institut, Villigen, Switzerland \\ **** now at: Universidad Andrés Bello, Santiago, Chile, and Massachusetts Institute of Technology, Cambridge, MA, USA
}

Received: 12 January 2010 - Published in Atmos. Chem. Phys. Discuss.: 9 February 2010

Revised: 11 June 2010 - Accepted: 20 June 2010 - Published: 9 July 2010

\begin{abstract}
An extensive set of measurements was made in and around Mexico City as part of the MILAGRO (Megacity Initiative: Local and Global Research Observations) experiments in March 2006. Simulations with the Model for Ozone and Related Chemical Tracers, version 4 (MOZART4), a global chemical transport model, have been used to provide a regional context for these observations and assist in their interpretation. These MOZART-4 simulations reproduce the aircraft observations generally well, but some differences in the modeled volatile organic compounds (VOCs) from the observations result from incorrect VOC speciation assumed for the emission inventories. The different types of CO sources represented in the model have been "tagged" to quantify the contributions of regions outside Mexico, as well as the various emissions sectors within Mexico, to the regional air quality of Mexico. This analysis indicates open fires have some, but not a dominant, impact on the atmo-
\end{abstract}

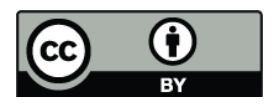

Correspondence to: L. K. Emmons (emmons@ucar.edu) spheric composition in the region around Mexico City when averaged over the month. However, considerable variation in the fire contribution $(2-15 \%$ of total $\mathrm{CO})$ is seen during the month. The transport and photochemical aging of Mexico City emissions were studied using tags of $\mathrm{CO}$ emissions for each day, showing that typically the air downwind of Mexico City was a combination of many ages. Ozone production in MOZART-4 is shown to agree well with the net production rates from box model calculations constrained by the MILAGRO aircraft measurements. Ozone production efficiency derived from the ratio of $\mathrm{O}_{\mathrm{x}}$ to $\mathrm{NO}_{\mathrm{z}}$ is higher in MOZART-4 than in the observations for moderately polluted air. $\mathrm{OH}$ reactivity determined from the MOZART-4 results shows the same increase in relative importance of oxygenated VOCs downwind of Mexico City as the reactivity inferred from the observations. The amount of ozone produced by emissions from Mexico City and surrounding areas has been quantified in the model by tracking NO emissions, showing little influence beyond Mexico's borders, and also relatively minor influence from fire emissions on the monthly average tropospheric ozone column. 


\section{Introduction}

The emissions from megacities are becoming an increasingly important influence on regional and global air quality (e.g., Mayer et al., 2000). Mexico City is one example of a developing megacity, with a population approaching 20 million in a growing urbanized area (Molina et al., 2007). While air quality has improved significantly in the past decade due to emissions control measures, pollution levels are still quite high in the Mexico City Metropolitan Area (MCMA) (de Foy et al., 2008). During March 2006 a large suite of measurements was made as part of the Megacity Initiative: Local and Global Research Observations (MILAGRO) in and around Mexico City from the ground and aircraft. MILAGRO consisted of four field campaigns that focused on local (MCMA-2006 and DOE/MAX-Mex) and regional scales (NSF/MIRAGE-Mex and NASA/INTEX-B), providing a comprehensive view of the emissions and nearfield chemistry within the MCMA, as well as the regional atmospheric composition. Details of the campaign measurements and field experiment designs are given in overview papers for INTEX-B (Singh et al., 2009) and the Mexico-based experiments (Molina et al., 2010). An overview of the meteorological conditions during MILAGRO is given by Fast et al. (2007). MILAGRO is the largest of a series of international campaigns in and around Mexico City, which also includes IMADA-AVER in 1997 (Edgerton et al., 1999) and MCMA-2003 (Molina et al., 2007).

While urban air quality analyses are usually assisted by regional models, global chemical transport models are valuable for providing a larger scale view of the regional impact. When global models are run at sufficiently high horizontal resolution they are also able to reproduce, and are valuable for the interpretation of, observations on a megacity to regional scale, as presented in this paper. Understanding the contributions of the various emissions sectors to the atmospheric composition in Mexico City is necessary for identifying control strategies for improving air quality. This work quantifies both the contributions from remote regions and within Mexico to the air over Mexico. Due to its impact on human health and crops, the sources of ozone are of particular interest. In addition to evaluating a model's ability to reproduce observed ozone contributions, the simulation of ozone precursors must also be accurate to properly understand ozone production. This work evaluates modeled ozone production in several ways.

After a brief description of the model and the setup for the simulations used here, comparisons between the model results and the observations are presented. The results of model simulations with "tagged" CO tracers are used, in Sect. 4, to illustrate the contributions of various pollution sources to the Mexico region and, in Sect. 5, to determine the physical age of the pollutants emitted from Mexico City and surrounding urban areas. After an evaluation of the modeled ozone production rate in Sect. 6, the amount of ozone produced by Mexico City emissions is presented in Sect. 7, followed by the conclusions.

\section{Model description}

Model simulations for this study were performed with MOZART-4 (Model for Ozone and Related chemical Tracers, version 4), a global chemical transport model for the troposphere (Emmons et al., 2010). It was run with the standard chemical mechanism, which includes 97 species and approximately 200 reactions. Many volatile organic compounds (VOCs) are included explicitly (e.g., ethane, propane, formaldehyde, acetaldehyde, acetone, methanol, isoprene), but higher hydrocarbons are lumped. For example, the MOZART-4 species BIGALK represents $\mathrm{C}_{4}$ and greater alkanes and other higher-carbon VOCs with similar reactivity and TOLUENE is a lumped aromatic (including toluene, benzene and xylenes). Photolysis rates were calculated using FTUV (Fast Tropospheric Ultraviolet and Visible radiation model), that takes into account the impact of the simulated clouds and aerosols, as described in Emmons et al. (2010).

\subsection{Meteorology and resolution}

For many studies using global chemical transport models, such as those that address large-scale questions or include multi-year analyses, the typical MOZART-4 horizontal resolution of $2.8^{\circ} \times 2.8^{\circ}$ (approximately $280 \mathrm{~km}$ ) is sufficient. However, for this analysis of the MILAGRO observations and Mexico City pollution, MOZART-4 was run at $0.7^{\circ} \times 0.7^{\circ}(70 \mathrm{~km})$. Model simulations at $2.8^{\circ} \times 2.8^{\circ}$ starting July 2005 were used to initialize the $0.7^{\circ} \times 0.7^{\circ}$ simulations covering 1-31 March 2006. The simulations presented here were run using the National Centers for Environmental Prediction (NCEP) Global Forecast System (GFS) meteorological fields (Kanamitsu et al., 1991), with 42 sigma levels in the vertical. A combination of analysis and forecast fields were used (00:00 UTC and 06:00 UTC analysis, 3-h forecast from 00:00 UTC, and 3-h through 15-h forecasts from 06:00 UTC), to provide meteorological inputs every $3 \mathrm{~h}$ to MOZART-4.

\subsection{Emissions}

The majority of the anthropogenic emissions used for this study come from the POET (Precursors of Ozone and their Effects in the Troposphere) database for 2000 (Granier et al., 2004), which includes anthropogenic emissions (from fossil fuel and biofuel combustion) based on the EDGAR-3 inventory (Olivier and Berdowski, 2001). The anthropogenic emissions (from fossil fuel and biofuel combustion) of black and organic carbon determined for 1996 are from Bond et al. (2004). For $\mathrm{SO}_{2}$ and $\mathrm{NH}_{3}$, anthropogenic emissions are from 


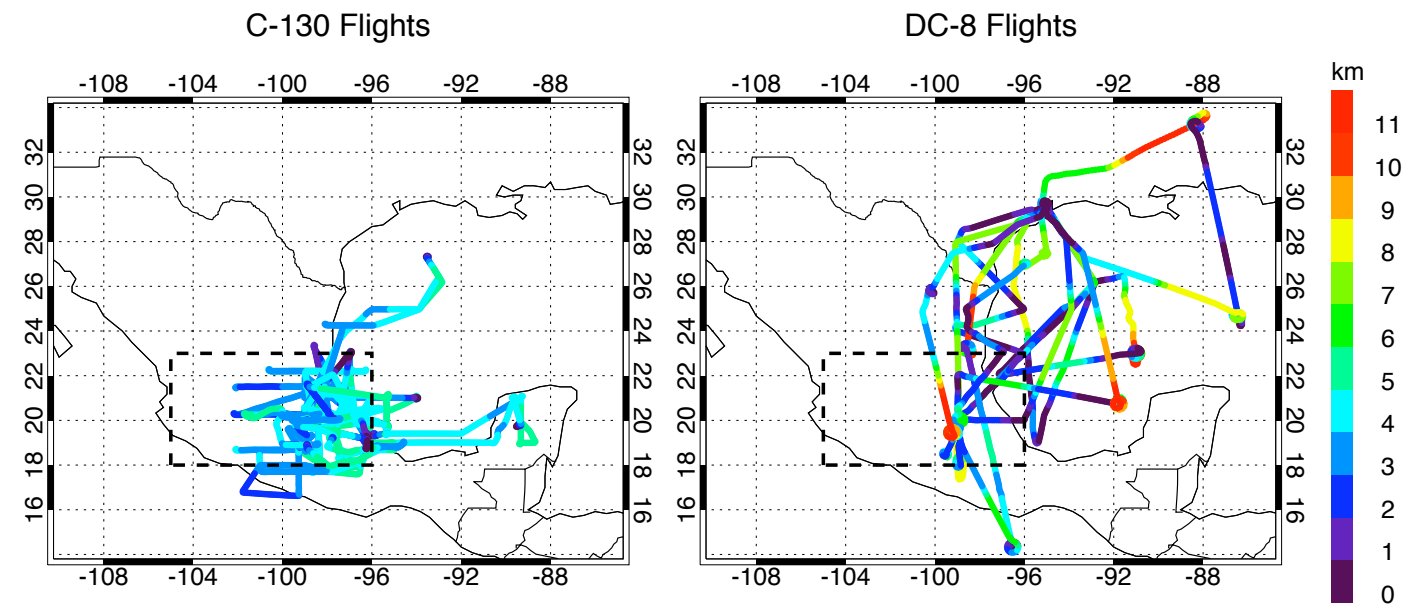

Fig. 1. Map of flights by the C-130 (4-29 March, 12 flights) and DC-8 (4-19 March, 6 flights), colored by pressure altitude above sea level.

the EDGAR Fast Track 2000 and EDGAR-2 databases, respectively (Olivier et al., 2005, 1999). For Asia, the 2006 inventory of Zhang et al. (2009) has been used. Aircraft emissions of $\mathrm{NO}, \mathrm{CO}$ and $\mathrm{SO}_{2}$ from scheduled, charter, general aviation and military traffic for 1999 are also included, as described in Emmons et al. (2010). Biomass burning emissions are from the Global Fire Emissions Database, version 2 (GFED-v2) (van der Werf et al., 2006). For species not provided in GFED-v2, such as individual VOCs, $\mathrm{SO}_{2}$ and $\mathrm{NH}_{3}$, emissions are determined by scaling the GFEDv2 $\mathrm{CO}_{2}$ emissions, using the included vegetation classification, by the emission factors of Andreae and Merlet (2001) and updates (Granier et al., 2004). Biogenic emissions of isoprene and monoterpenes are calculated online based on the Model of Emissions of Gases and Aerosols in Nature (MEGAN) (Guenther et al., 2006), as described in Emmons et al. (2010), with emission factors from MEGAN v2.0. Other natural emissions, NO from soil and lightning, and DMS from oceans, are included as in the standard MOZART4 configuration (Emmons et al., 2010). Dust is not calculated in MOZART-4, but included as a climatological average distribution, as described in Emmons et al. (2010). The volcanoes circling Mexico City are an important source of $\mathrm{SO}_{2} . \mathrm{SO}_{2}$ emissions from continuously outgassing volcanoes from the GEIA-v1 inventory (Andres and Kasgnoc, 1998) are included in MOZART-4. These emissions include $1.32 \times 10^{11} \mathrm{molecules} / \mathrm{cm}^{2} / \mathrm{s}$ in a $1^{\circ}$ grid, resulting in total emissions of $4.3 \mathrm{Gg}-\mathrm{SO}_{2}$ for March. Grutter et al. (2008) report observations of $2.45 \pm 1.39 \mathrm{Gg}$ /day of $\mathrm{SO}_{2}$ emitted from the Popocatépetl volcano averaged over March 2006 ( $76 \mathrm{Gg}$ total for March). These results were published after the MOZART-4 simulations were completed, so are not included in these results.

For this study, the anthropogenic and biomass burning emissions for Mexico have been replaced with higher resolution inventories. The anthropogenic emissions from the
Table 1. Emissions in Central Mexico $\left(18-23^{\circ} \mathrm{N}, 255-264^{\circ} \mathrm{E}\right)$ for March 2006, and fraction of emissions from open fires, from the emissions inventories used in this study (see Sect. 2.1).

\begin{tabular}{lrr}
\hline Species & $\begin{array}{r}\text { Emissions } \\
(\mathrm{Gg})\end{array}$ & $\begin{array}{r}\text { Fire fraction } \\
(\%)\end{array}$ \\
\hline $\mathrm{NO}$ & 53.9 & 16 \\
$\mathrm{CO}$ & 640.7 & 39 \\
$\mathrm{C}_{2} \mathrm{H}_{6}$ & 8.7 & 19 \\
$\mathrm{C}_{3} \mathrm{H}_{8}$ & 16.4 & 3 \\
$\mathrm{C}_{2} \mathrm{H}_{4}$ & 6.3 & 50 \\
$\mathrm{C}_{3} \mathrm{H}_{6}$ & 3.0 & 48 \\
Lumped alkane (BIGALK) & 138.0 & 1 \\
Lumped alkene (BIGENE) & 8.2 & 18 \\
Lumped aromatic (TOLUENE) & 30.7 & 10 \\
Isoprene (ISOP) & 194.3 & 0 \\
Terpenes $\left(\mathrm{C}_{10} \mathrm{H}_{16}\right)$ & 13.7 & 0 \\
$\mathrm{CH}_{2} \mathrm{O}$ & 4.3 & 78 \\
$\mathrm{CH}_{3} \mathrm{CHO}$ & 5.9 & 64 \\
$\mathrm{CH}_{3} \mathrm{COCH}$ & 5.6 & 77 \\
$\mathrm{MEK}$ & 4.0 & 86 \\
$\mathrm{CH}_{3} \mathrm{OH}$ & 38.9 & 82 \\
$\mathrm{C}_{2} \mathrm{H}_{5} \mathrm{OH}$ & 2.6 & 11 \\
$\mathrm{SO}_{2}$ & 137.2 & 2 \\
$\mathrm{DMS}^{\mathrm{NH}_{3}}$ & 0.3 & 0 \\
$\mathrm{Black}_{\text {Organic carbon (BC) }}$ & 60.7 & 4 \\
& 3.8 & 40 \\
\hline
\end{tabular}

Mexico National Emissions Inventory (NEI) for 1999 (http: //www.epa.gov/ttn/chief/net/mexico.html) are used. This inventory is provided as totals per state so it was gridded based on population and road locations to $0.025^{\circ}(2.5 \mathrm{~km})$. Updated inventories exist for Mexico City, as summarized by Fast et al. (2009), but are not used in this study. While the 
Table 2. Measurements used in model evaluation.

\begin{tabular}{|c|c|c|}
\hline Parameter & Instrument name, technique & PI, reference \\
\hline \multicolumn{3}{|c|}{ C-130 } \\
\hline $\mathrm{O}_{3}$ & NCAR- $\mathrm{NO}_{x y} \mathrm{O}_{3}$, chemiluminescence & Weinheimer (Walega et al., 1991) \\
\hline $\mathrm{NO}, \mathrm{NO}_{2}, \mathrm{NO}_{\mathrm{y}}$ & NCAR- $\mathrm{NO}_{x y} \mathrm{O}_{3}$, chemiluminescence & Weinheimer (Walega et al., 1991) \\
\hline $\mathrm{CO}$ & NCAR, vacuum UV resonance fluorescence & Campos (Gerbig et al., 1999) \\
\hline $\mathrm{SO}_{2}$ & NOAA, pulsed UV fluorescence & Holloway \\
\hline $\mathrm{CH}_{2} \mathrm{O}$ & NCAR DFG-TDL & Fried, Weibring \\
\hline OVOCs & TOGA / Fast GC-MS & Apel (Apel et al., 2010) \\
\hline aerosol composition & high-resolution AMS & Jimenez (DeCarlo et al., 2006, 2008) \\
\hline soot & SP-2, single particle soot photometer & Kok \\
\hline \multicolumn{3}{|c|}{ DC-8 } \\
\hline $\mathrm{O}_{3}$ & NASA Langley FASTOZ, chemiluminescence & Avery \\
\hline $\mathrm{CO}$ & DACOM, TDL & Sachse (Sachse et al., 1987) \\
\hline $\mathrm{OH}, \mathrm{HO}_{2}$ & ATHOS & Brune \\
\hline NMHCs & UCI canister samples, GC-MS & Blake \\
\hline $\mathrm{H}_{2} \mathrm{O}_{2}, \mathrm{CH}_{3} \mathrm{OOH}$ & URI, HPLC & Heikes \\
\hline photolysis rates & Scanning Actinic Flux Spectroradiometer (SAFS) & Shetter, Hall (Shetter and Müller, 1999) \\
\hline
\end{tabular}

TOGA: Trace Organic Gas Analyzer; OVOCS: (methanol, acetaldehyde and acetone) aerosol comp. (submicron): sulfate, nitrate, chloride, ammonium, organic aerosol.

more recent Mexico City inventories are more detailed, and presumably more accurate, Mexico City is represented by a single model grid box in our study, so were not included. $\mathrm{NO}_{\mathrm{x}}$ emissions are emitted as NO in MOZART-4 and the partitioning between $\mathrm{NO}$ and $\mathrm{NO}_{2}$ is calculated explicitly in the chemistry. The emissions for VOCs are only available as lumped total VOCs, so speciation to the MOZART VOCs was based on ratios to CO in the POET inventory. The fire emissions for North America have been replaced by an inventory based on daily MODIS fire counts, following Wiedinmyer et al. (2006). Emissions for individual fires were calculated and then gridded to the simulation resolution. The totals for the emissions from Central Mexico $\left(18-23^{\circ} \mathrm{N}, 255-\right.$ $264^{\circ} \mathrm{E}$ ) for March 2006 using these inventories are given in Table 1. This region is much larger than the MCMA and includes the fires around the city that impact the regional air quality, along with a number of other major cities. The fraction of emissions from open fires averaged over the month is also given in Table 1.

\section{Model evaluation}

MILAGRO included many ground-based and airborne measurements, covering broad spatial and temporal scales. The aircraft measurements from the NSF/NCAR C-130 and the NASA DC-8 sampled both the Mexico City urban area and the surrounding region over Mexico and the Gulf of Mexico, particularly in the pollution outflow. Figure 1 shows the location and altitude of the flights used in the following analyses, including the $12 \mathrm{C}-130$ flights between 4 and 29 March, and the 6 DC- 8 flights between 4 and 19 March. Descriptions of the instrument payloads of the C-130 and DC- 8 are given by Molina et al. (2010) and Singh et al. (2009). The measurements used in this work are listed in Table 2.

The C-130 and DC- 8 measurements best match the scale of the MOZART-4 simulations and the scale of the analyses presented here. The DOE G-1 aircraft also provided a comprehensive suite of gas-phase and aerosol measurements (Molina et al., 2010), but as the flights were limited to the region directly surrounding the Mexico City basin, only a few MOZART grid boxes were covered. Due to the large model grid size it is also not expected that the model would reproduce the surface site observations very well.

Summaries of the comparisons between the MOZART-4 simulations for the MILAGRO period and the C-130 and DC8 aircraft observations are shown in Figs. 2-5. MOZART-4 3 -h average results have been interpolated to the time and location of the aircraft measurements. The measurements and model results for all flights have been binned into $0.5 \mathrm{~km}$ altitude bins, and the median and quartiles are shown for each bin. Since Mexico City is at an elevation of $2.3 \mathrm{~km}$ above sea level (a.s.l.), these profiles show relatively high values for most species at $2-4 \mathrm{~km}$ due to the sampling focused directly over the city and in its outflow. The C-130 was based in Veracruz, Mexico, and the DC-8 in Houston, Texas, so the measurements below $2 \mathrm{~km}$ are primarily within the vicinity of those cities.

Separate comparisons are made for the measurements within central Mexico (Figs. 2 and 4), and outside this region (Figs. 3 and 5). Generally higher mixing ratios are found 

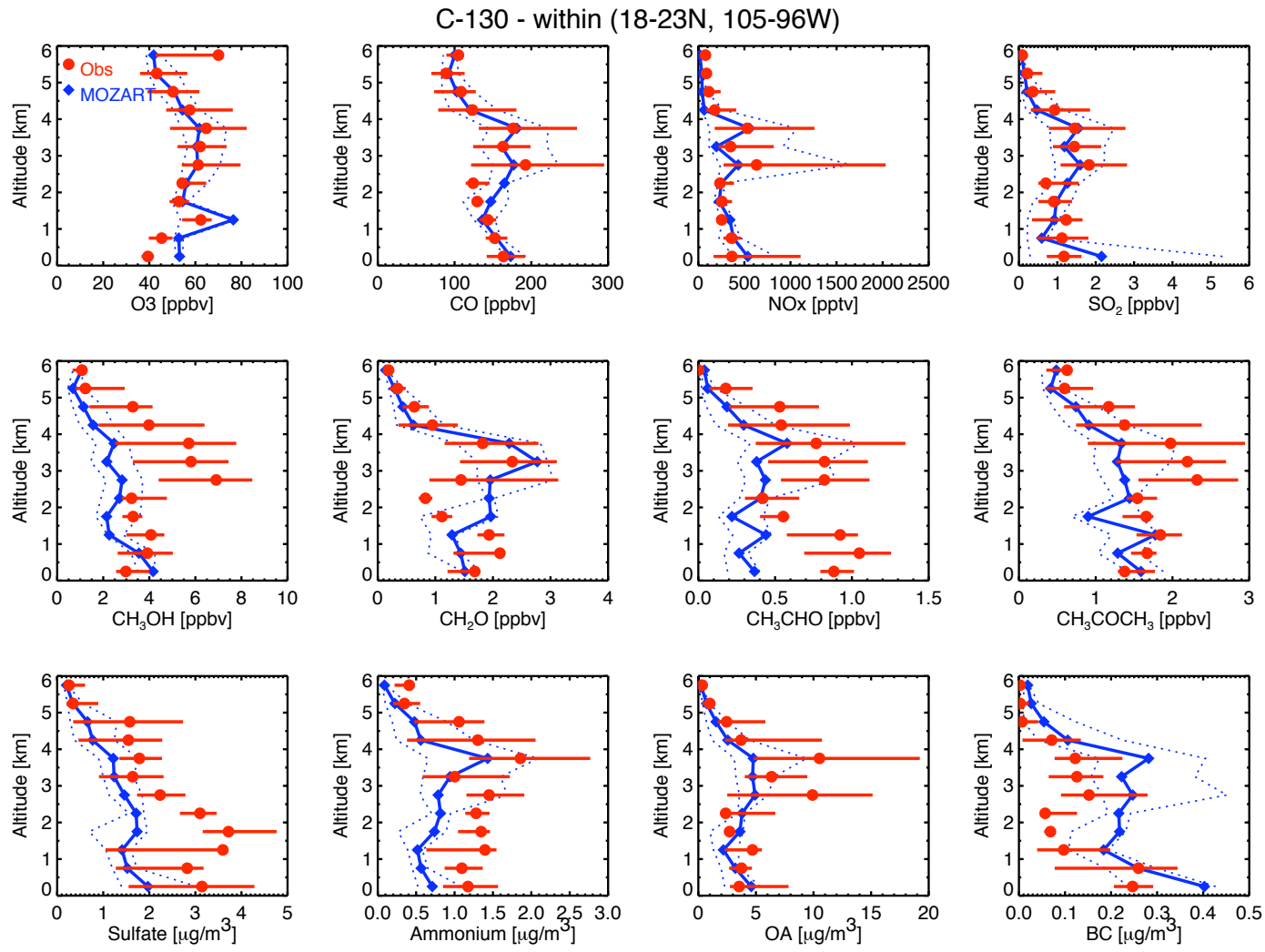

Fig. 2. Comparison of MOZART results to C-130 observations within the Central Mexico box shown in Fig. 1. Model results have been interpolated to flight tracks and then binned by pressure altitude. Symbols indicate the median, with error bars and dashed lines indicating the quartiles, of each $0.5-\mathrm{km}$ bin.

within the Central Mexico box than outside it. The simulated ozone values agree very well with observations from the C130 and DC-8, as do several of the ozone precursors, such as $\mathrm{CO}$ and $\mathrm{NO}_{\mathrm{x}}\left(\mathrm{NO}+\mathrm{NO}_{2}\right)$. The model substantially underestimates a number of the oxygenated VOCs (OVOCs), such as methanol, acetaldehyde and acetone, as shown in Figs. 2 and 3, most likely the result of too low emissions of these species or their precursors (discussed below). While the $\mathrm{SO}_{2}$ measurements are reproduced fairly well, sulfate aerosols are underestimated by the model, indicating possible model errors in the formation or loss of sulfate. However, it is likely that the $\mathrm{SO}_{2}$ emissions are underestimated, with a compensating error of the oxidation to sulfate being too slow. Much of the $\mathrm{SO}_{2}$ emissions in Central Mexico are due to the volcanoes and petrochemical complexes, and are likely underestimated, as discussed above in Sect. 2.2. MOZART-4 simulates organic carbon aerosols (OC), so to compare to the observed organic aerosol (OA), they been scaled by an OA/OC ratio of 1.8 (Aiken et al., 2008) and then added to the modeled secondary organic aerosol (SOA). The vertical profile of the modeled OA agrees fairly well with the observations, but with some significant under-predictions at times. This is surprising given the very low SOA formation in MOZART-4. Along the C-130 flight legs, the simulated SOA concentra- tions are on average about $3 \%$ of the total organic aerosol. The unrealistically low modeled SOA results are consistent with previous comparisons of MOZART-4 with observations (Dunlea et al., 2009), as well as many other models for Mexico City (Volkamer et al., 2006; Dzepina et al., 2009; Fast et al., 2009; Hodzic et al., 2009; Tsimpidi et al., 2009) and other areas (as summarized by Heald et al., 2005; Hallquist et al., 2009; de Gouw and Jimenez, 2009). Since total OA is well predicted despite the lack of a realistic SOA source, most likely another OA source is overestimated. Since urban primary OA is underpredicted by the Mexico City emissions inventory (Fast et al., 2009; Aiken et al., 2009), this suggests that fire emissions of OA may be too high in the model. Black carbon concentrations are slightly overestimated, consistent with the conclusion of Fast et al. (2009) that the fire emissions, and possibly also the anthropogenic, inventories are too high for black carbon.

Since the DC- 8 has greater vertical range than the C-130, the plots in Figs. 4 and 5 show a greater extent of the free troposphere. As for the $\mathrm{C}-130$ comparisons, $\mathrm{O}_{3}$ and $\mathrm{CO}$ are reproduced well by the model, both within and outside the Central Mexico box. The model under-predicts the $\mathrm{OH}$ measurements, but matches $\mathrm{HO}_{2}$ quite well when compared to the DC- 8 measurements. The comparison with the C-130 

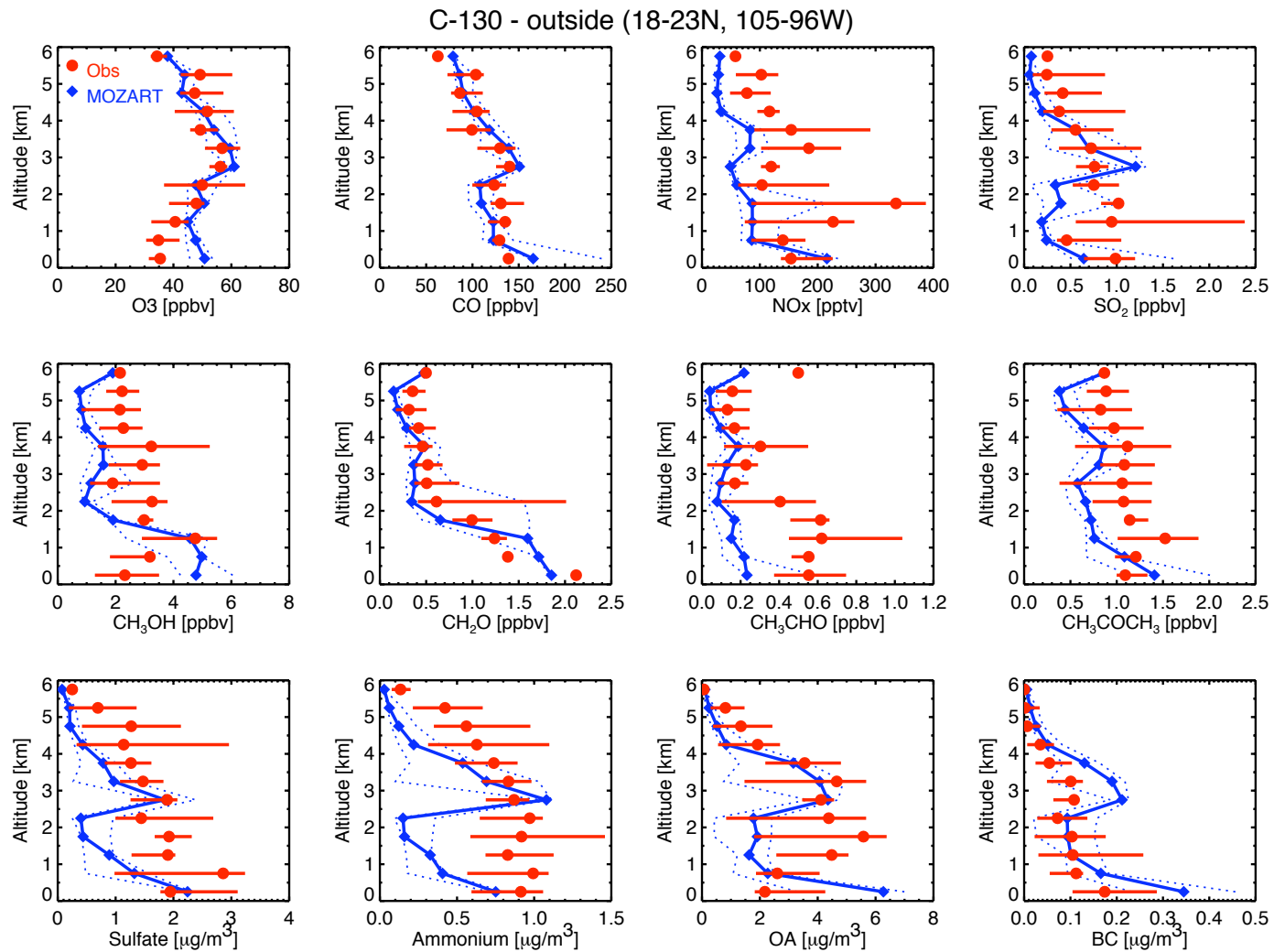

Fig. 3. Comparison of MOZART results to C-130 observations outside of Central Mexico box, as Fig. 2.

observations (not shown) indicates MOZART-4 simulates $\mathrm{OH}$ well, but underestimates $\mathrm{HO}_{2}$. The difference between the aircraft in model-measurement comparisons could be due to the different chemical regimes sampled by the two aircraft. Overall, the model slightly underestimates $\mathrm{HO}_{\mathrm{x}}$. There are significant emissions of propane in Mexico City due to prevalent use of liquified petroleum gas (LPG), but the model prediction of propane roughly agrees with observations. The most substantial discrepancy in the nonmethane hydrocarbons (NMHCs) is in the model over-prediction of the lumped alkane BIGALK, which is compared to the sum of $i$ - and $n$-butane, $i$ - and $n$-pentane, $n$-hexane and $n$-heptane. The lumped aromatic TOLUENE is compared to the sum of benzene, toluene, ethylbenzene and $m-, p$ - and $o$-xylene, all measured by the UC-Irvine group. Errors in the VOC speciation of the emissions are likely the source of these errors. The model over-predicts $\mathrm{H}_{2} \mathrm{O}_{2}$ in the lower troposphere, while $\mathrm{CH}_{3} \mathrm{OOH}$ is simulated well. The "observed" photolysis frequencies of $\mathrm{J}\left(\mathrm{O}^{1} \mathrm{D}\right)$ and $\mathrm{J}\left(\mathrm{NO}_{2}\right)$ are from calculations of the Tropospheric Ultraviolet and Visible (TUV) radiation model (Madronich and Flocke, 1999) based on the actinic flux measurements. The MOZART-4 results slightly underestimate the observations, particularly at higher altitudes. One cause of this discrepancy could be in the representation of clouds in MOZART-4. While atmospheric water vapor and clouds are calculated in the model based on the surface water flux from the driving meteorological fields, it is possible the simulated clouds are not accurate, and thus affect the photolysis.

To further investigate the discrepancies between the model and observations, comparisons have been made for the correlations between VOCs and CO. Tracer-tracer scatter plots such as these have the advantage of reducing the importance of model errors in transport and diffusion and facilitate meaningful comparisons to observations. Figure 6 shows the correlations between several NMHCs and OVOCs for the C-130 measurements, and the corresponding model results, that lie within the Central Mexico region defined above. The MOZART-4 results overestimate the ethane concentrations, but underestimate all the other species shown here. These discrepancies are most likely primarily due to errors in the emissions inventory used. As described above, this study used the Mexico NEI database that only provided total VOC emissions and we applied the speciation of the POET inventory (which originated from EDGAR-2). The VOC speciation of emissions in Mexico City is quite different from US cities (e.g., Apel et al., 2010; Velasco et al., 2007). One difference is the large-scale use of LPG resulting in higher propane levels than other cities, consistent with the low model values here. Significantly lower methanol values were predicted by MOZART-4 than observed within the Central Mexico box. While fires are a significant source of methanol, it is possible the anthropogenic 

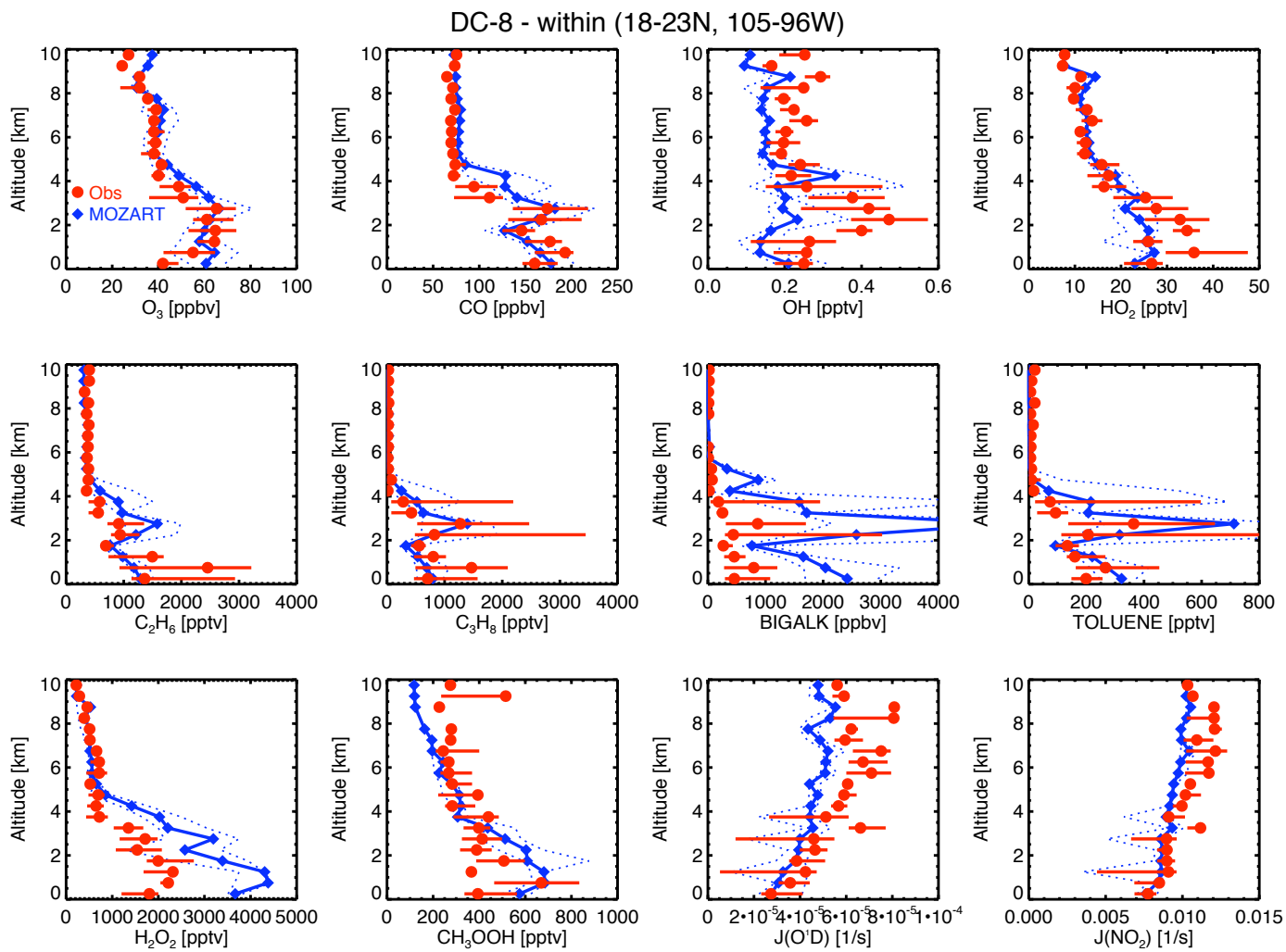

Fig. 4. Comparison of MOZART results to DC-8 observations within Central Mexico box, as Fig. 2.

inventory significantly underestimates the vehicle emissions of $\mathrm{CH}_{3} \mathrm{OH}$ in Mexico City, as suggested by Velasco et al. (2009), and consistent with the analysis of Apel et al. (2010). The correlations of several species show two distinct branches in the MOZART-4 results, indicative of different emission factors for fire and traffic emissions, with some mixing between the two types of emissions. The scatter in the observations indicate that the sampled air was also a mixture of air influenced by fire and traffic (and other urban) emissions. Formaldehyde, acetaldehyde and acetone are all fairly well reproduced by the model, which may be a result of these species having substantial secondary sources (Apel et al., 2010; de Gouw et al., 2009) and therefore less influenced by underestimates of their direct emissions.

\section{Impact of Mexico City emissions on CO distributions}

Since CO is a good tracer of long-range pollution transport, having a lifetime of several weeks and is well-correlated with many other pollutants as shown in Fig. 6, it is a useful species to use to examine the impact of Mexico City on the regional atmosphere and the impact of other regions on Mexico. The different types and regions of CO sources have been "tagged" in the model by creating additional tracers, with each tracer having emissions from a single region or source type and loss rates equal to the loss rate total $\mathrm{CO}$ experiences. These tracers can then be used to quantify the contributions from various sources at any given location. Figure 7 shows the March 2006 monthly mean column averages for CO mixing ratio and fractional contributions of the tagged $\mathrm{CO}$. For each panel, the column is shown as the pressure-weighted average of the mixing ratio below $400 \mathrm{hPa}$ (approximately $6 \mathrm{~km}$ a.s.1.), or, for the upper right panel, below $1 \mathrm{~km}$ altitude above the surface.

In the two plots of $\mathrm{CO}$ (top row of Fig. 7), the emissions from Mexico City and surrounding cities are clearly evident, but do not seem to have a strong influence beyond the borders of Mexico, due to the limited source strength of the MCMA in the larger regional context. However, under certain meteorological conditions, it is possible for fairly concentrated plumes of pollution from Mexico City to be carried across the Gulf of Mexico and into the United States, as discussed below (Sect. 5). The prevailing winds from the west bring fairly clean air from the tropical Pacific over Mexico, diluting the local pollution.

The lower six panels of Fig. 7 show the relative contributions of the major source regions to the total CO over Mexico. Each region tag is the sum of anthropogenic and fire emissions. The "Central Mexico" panel shows CO from emissions in the region indicated in Fig. 8. The contribution of emissions in Mexico and Central America, which includes the Central Mexico tags of the first panel, logically is the 

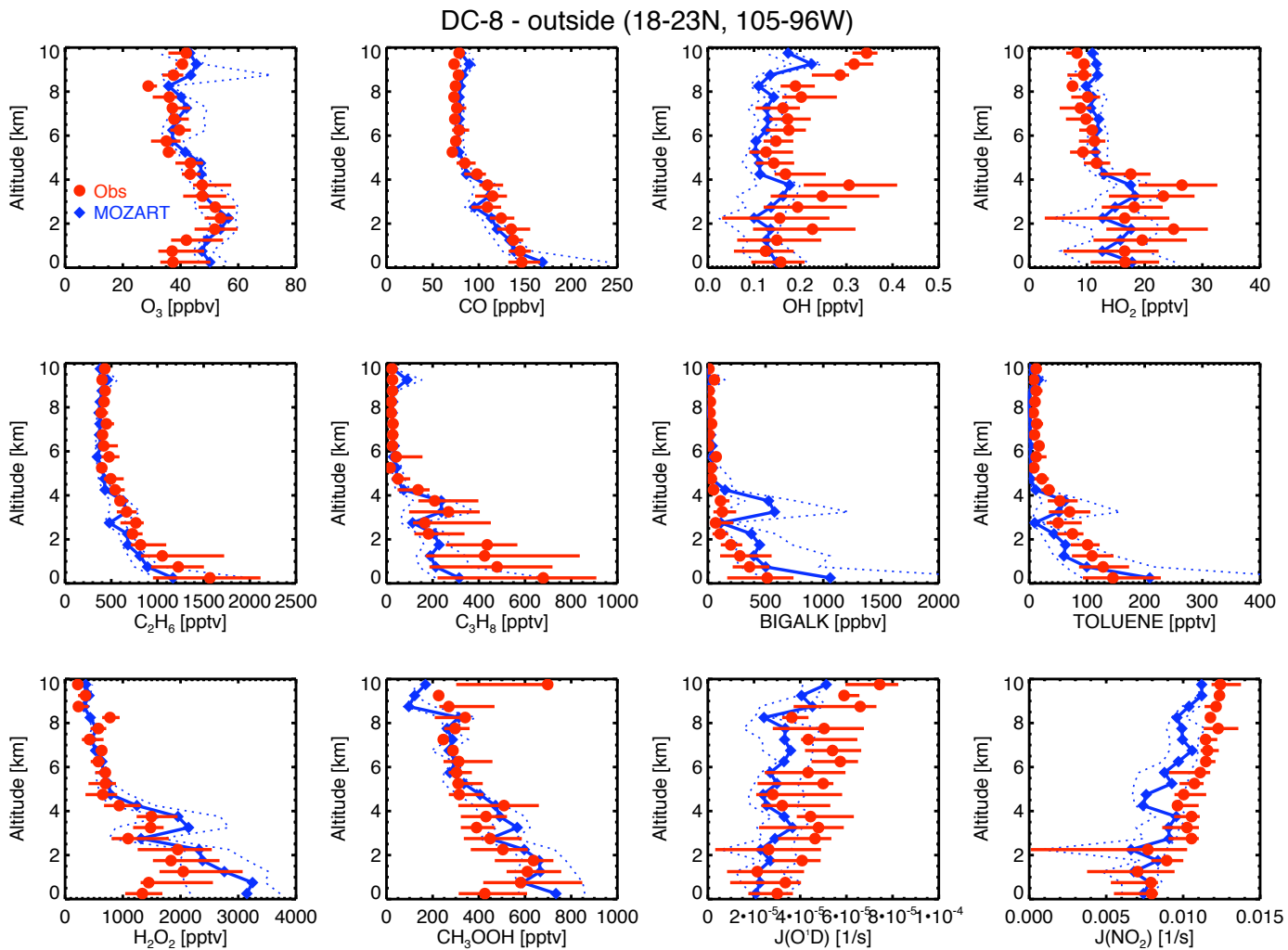

Fig. 5. Comparison of MOZART results to DC-8 observations outside Central Mexico box, as Fig. 2.

most significant source in Mexico. During this month on average, there was little impact of the US and Canada on Mexico, but $10 \%$ of the tropospheric $\mathrm{CO}$ was from Asia, with the contribution increasing to the north.

While urban $\mathrm{CO}$ concentrations are dominated by direct emissions, roughly half of the $\mathrm{CO}$ in the free troposphere is from secondary production, as shown in the bottom right panel of Fig. 7. Approximately half of this contribution is from the oxidation of $\mathrm{CH}_{4}$. Much of the $\mathrm{CO}$ from methane is produced in the Tropics, where $\mathrm{OH}$ levels are high, and then transported to higher latitudes. In the region plotted, the highest fraction of secondary $\mathrm{CO}$ is over the relatively cleaner air over the Pacific. While the fraction is less over Mexico City and the US, significant secondary $\mathrm{CO}$ is produced in those regions.

To track the influence of Mexico City emissions, CO from anthropogenic (primarily traffic) and open fire emissions were tagged separately. The monthly average anthropogenic and fire emissions of $\mathrm{CO}$ for the Central Mexico region (as defined for this study) are mapped separately in the top panels of Fig. 8. This region includes emissions from the many large cities that ring Mexico City, including Cuernavaca, Puebla, Toluca, and Pachuca. Many of these cities have less stringent pollution controls than Mexico City, thus their emissions are a significant contributor to the region. A significant portion of the open burning during March took place in the hillsides surrounding Mexico City, so the emissions on the scale of the model grid overlap with the anthropogenic emissions. Averaged over the month, the fire emissions are about $40 \%$ of the total CO emissions over the Central Mexican Plateau (see Table 1). However, the open fire emissions are not as concentrated in the city as the anthropogenic sources (Crounse et al., 2009; Aiken et al., 2010) and have a substantially smaller contribution to the regional CO distribution (10-15 ppbv vs. $20-50$ ppbv).

Figure 9 shows the tropospheric CO column averaged over the Central Mexico region and the various source contributions from 6-h MOZART-4 output. Results are shown for the column averaged from the surface to $400 \mathrm{hPa}$ (about $6 \mathrm{~km}$ a.s.l.) as well as for $0-2 \mathrm{~km}$ above the surface. Almost half of the tropospheric column is from photochemical production; approximately $45 \mathrm{ppbv}$ on average over the month and evenly divided between oxidation of methane and nonmethane hydrocarbons. The Southern Hemisphere, Europe and Africa contributions are relatively small and fairly constant. Much of the total CO variability is due to the varying amounts of fire influence on the area, but also to the changes in contributions from Asia and the US due to shifts in transport patterns. On 20 March the winds shifted to northerly and a rainy period began, suppressing the fires in the region (Fast et al., 2007). This also led to minor increases in the pollution from the US and Asia. In the contributions marked 

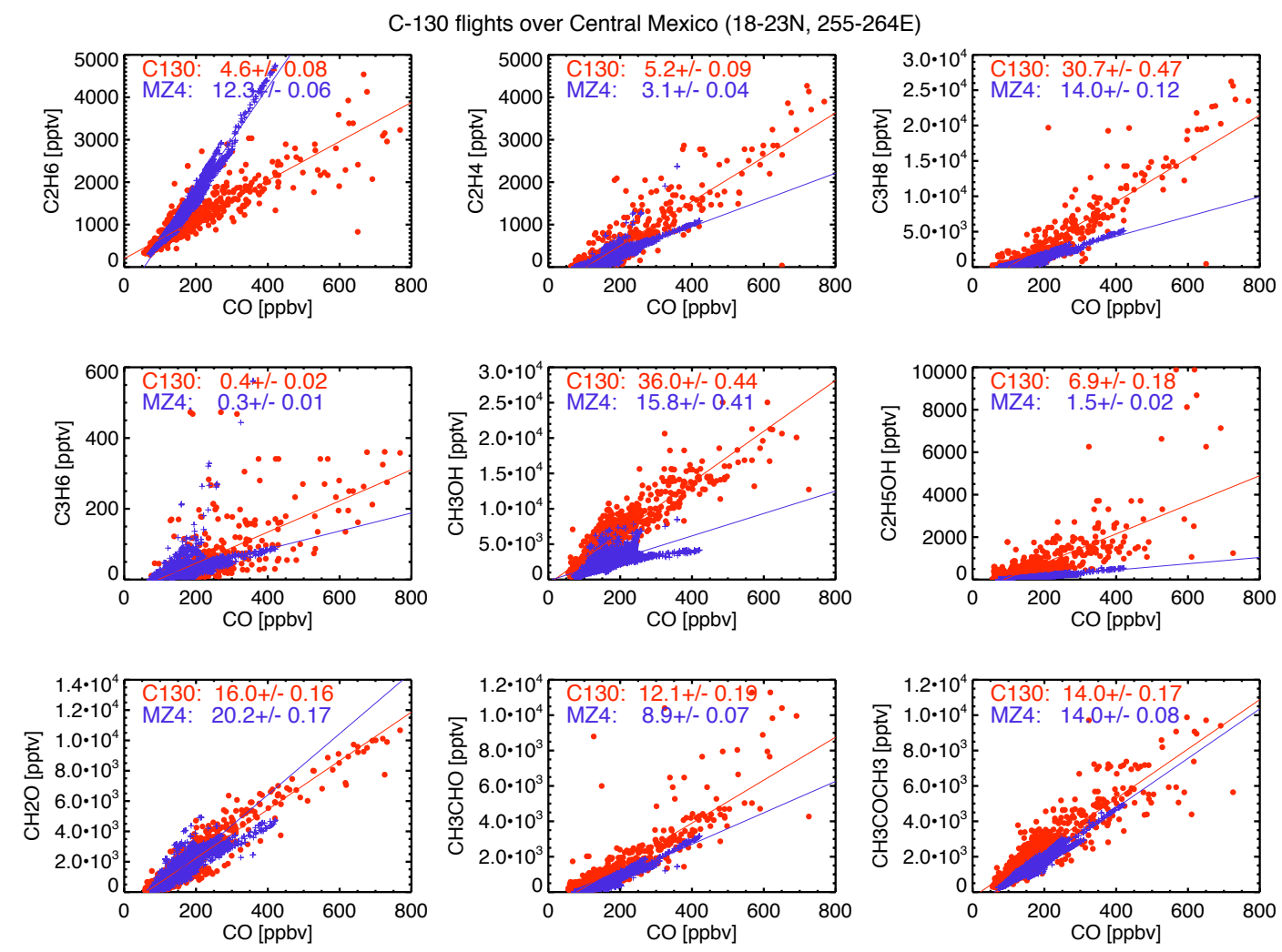

Fig. 6. Correlations between VOCs and CO for MOZART (MZ4) results and C-130 observations for portions of all flights within Central Mexico $\left(18-23^{\circ} \mathrm{N}, 105-96^{\circ} \mathrm{W}\right)$. The slope and its uncertainty from the linear regression of each VOC to CO is given.

"Mex-Anthro" and "Mex-Fires" the dashed lines show the contribution from the Central Mexico region as opposed to all of Mexico and Central America indicated by the colored area. It is clear the Mexico City fire contribution became a much smaller fraction of the Mexico and Central America fires after 20 March, but fires from outside Central Mexico (e.g., the Yucatan) had a considerable influence on the region. Similar features are seen in the $0-2-\mathrm{km}$ average, but with greater variability in the direct source contributions, as well as the NMHC oxidation contribution resulting from the urban and fire emissions. Around 10 March the contribution from fires in Central Mexico is about $12 \%$ of total CO, but drops to less than 5\% after 20 March.

Several other studies have analyzed the MILAGRO observations to estimate the contribution of fires to the atmospheric composition around Mexico City. Yokelson et al. (2007) estimate $15 \%$ or $25 \%$, depending on the type of analysis, of the $\mathrm{CO}$ emitted from the Mexico City area is from fires. Crounse et al. (2009) estimate that one third of the $\mathrm{CO}$ is from fires over the larger scale, with a smaller contribution directly over Mexico City. The fraction of organic aerosol (OA) due to fires inside Mexico City is $15-20 \%$ (Stone et al., 2008; Querol et al., 2008; Aiken et al., 2009, 2010). Both CO and OA have a substantially lower impact on the ground compared to aloft (DeCarlo et al., 2008; Crounse et al., 2009). Karl et al. (2009) estimate $0-10 \%$ of the observed aromatic compound concentrations are from biomass burning. Another potential source of information about the relative contribution of anthropogenic and biomass burning emissions is from ${ }^{14} \mathrm{C}$ isotopic ratio measurements, however interpretation of the results is quite complex due to the contamination of wood by nuclear bomb radiocarbon and other enriched sources (Vay et al., 2009; Aiken et al., 2010). The fraction of fire emissions in the inventory used here (see Table 1) varies greatly among species, depending both on the fire emissions factors and on the magnitude of anthropogenic and natural emissions in this region. The fractions in the inventory calculated here are generally in the range of the observations-derived conclusions.

\section{Age of Mexico City pollution}

An estimate of the age of an observed airmass is needed to relate it to source emissions and understand its chemical processing. Of particular interest for MILAGRO is quantifying Mexico City emissions based on observations of air transported from the city. In most cases the photochemical age is of primary interest and can be estimated from the oxidation 

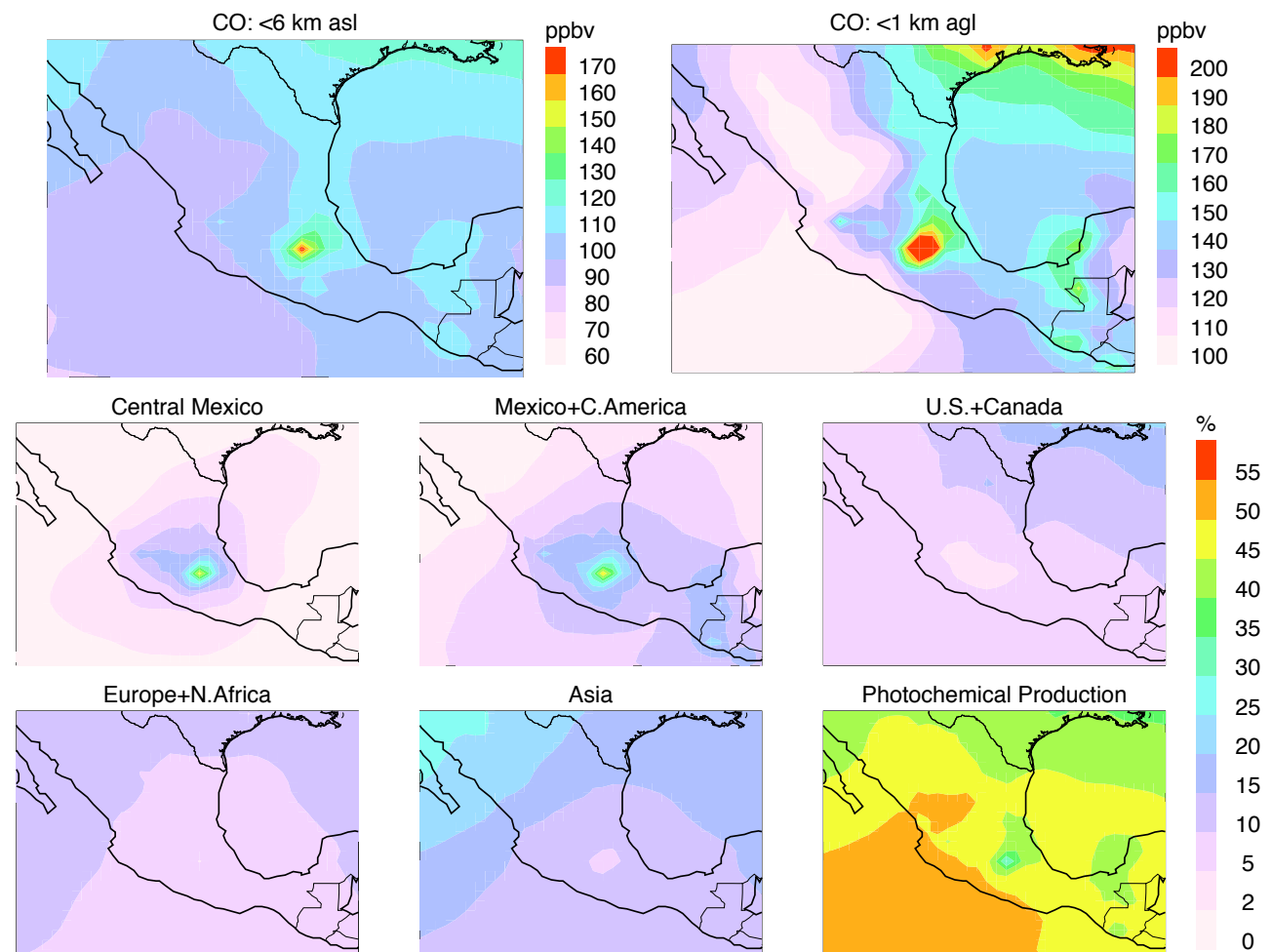

Fig. 7. Top, left: CO averaged for 1-31 March 2006 over the tropospheric column (surface to $6 \mathrm{~km}$, or $400 \mathrm{hPa}$, a.s.1.); top right: same, averaged over the lowest $\mathrm{km}$ above the surface. Middle and bottom rows: fraction of tagged $\mathrm{CO}$ to total $\mathrm{CO}$ averaged over the tropospheric column.
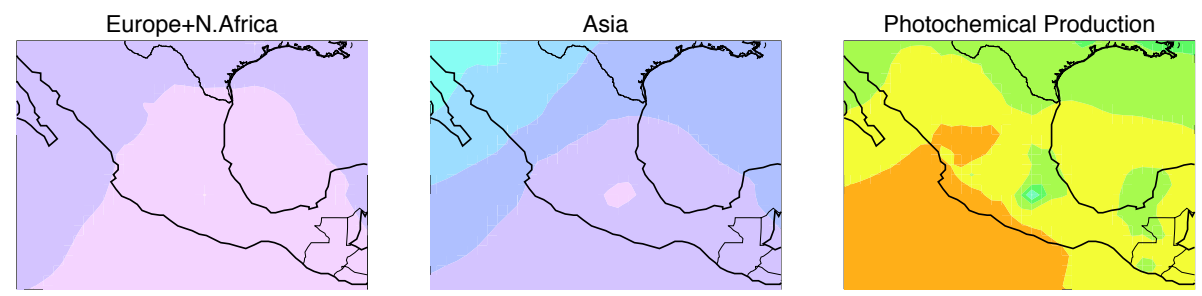

5



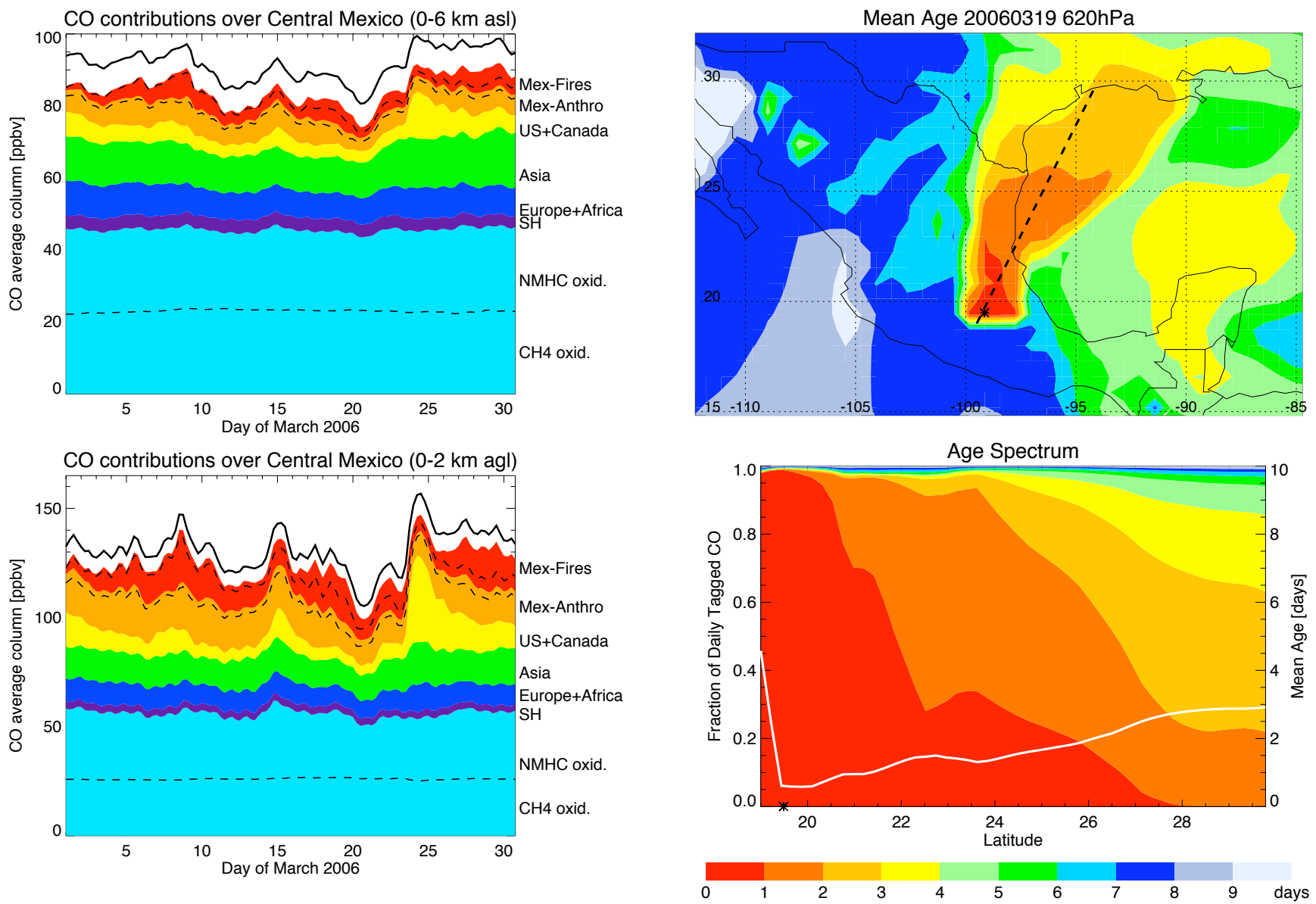

Fig. 9. Contributions of source regions to $\mathrm{CO}$ over Central Mexico region, 1-31 March 2006, for average columns, top: below $6 \mathrm{~km}$ a.s.l., bottom: below $2 \mathrm{~km}$ above the surface. Black line: total $\mathrm{CO}$; light blue region is total chemical production, with dashed line separating methane and non-methane hydrocarbon oxidation terms; orange and red regions show contribution from anthropogenic and fire emissions, respectively, for all of Mexico and Central America, with dashed lines showing contribution from just Central Mexico. Difference between total CO and sum of tags is due to natural CO emissions from vegetation and the ocean.

of $\mathrm{NO}_{\mathrm{x}}$ to $\mathrm{NO}_{\mathrm{y}}$ (Kleinman et al., 2008) or the ratio of hydrocarbons with different lifetimes, e.g., toluene/benzene (e.g., Warneke et al., 2007; Apel et al., 2010). The physical age of the airmass can be estimated from MOZART- 4 results by tagging the $\mathrm{CO}$ emissions in and around Mexico City for each day. These tags have been used to assist in the interpretation of data sampled by the C-130 flight on 8 March 2006 (DeCarlo et al., 2008).

A particularly strong outflow event from Mexico City occurred on 19 March, producing a clear plume of pollution to the northeast of Mexico City that was sampled by the C130 aircraft and reproduced well by MOZART-4. The top panel of Fig. 10 shows the mean age of Mexico City pollution in this plume at the $620 \mathrm{hPa}$ pressure level $(\approx 4 \mathrm{~km}$ a.s.l. $)$.

Fig. 10. Mean age (top) and age spectrum (bottom) of CO emitted from Mexico City on 19 March at $620 \mathrm{hPa}(4 \mathrm{~km})$, derived from the MOZART-4 tagged CO for each day. Bottom panel shows the contributions of each day's Mexico City CO emissions along the dashed line in top panel, with the mean age plotted as the white line against the right axis. Asterisk in both panels indicates location of Mexico City.

A large region directly over Mexico City and stretching to the northeast is less than a day old. The plume has a mean age of 1-2 days along the Gulf coast of Northern Mexico and Southern Texas, and then 2-3 days as it reaches Louisiana. Just north of the Yucatan peninsula is a region containing 3day-old Mexico City pollution that has circulated back southward. The high values of mean age shown over the western part of Mexico show the pollution does not frequently get transported to that region.

The bottom panel of Fig. 10 shows the age spectrum along the plume (along the black dashed line plotted in the top panel). The spectrum is shown by plotting the relative fraction of the CO tags emitted for the previous 10 days. The age spectrum plot starts on the southwest edge of the city, with a mean age of about 4 days. While the majority of the air is from fresh emissions, a small fraction of older air increases the mean age substantially. For the region near the 

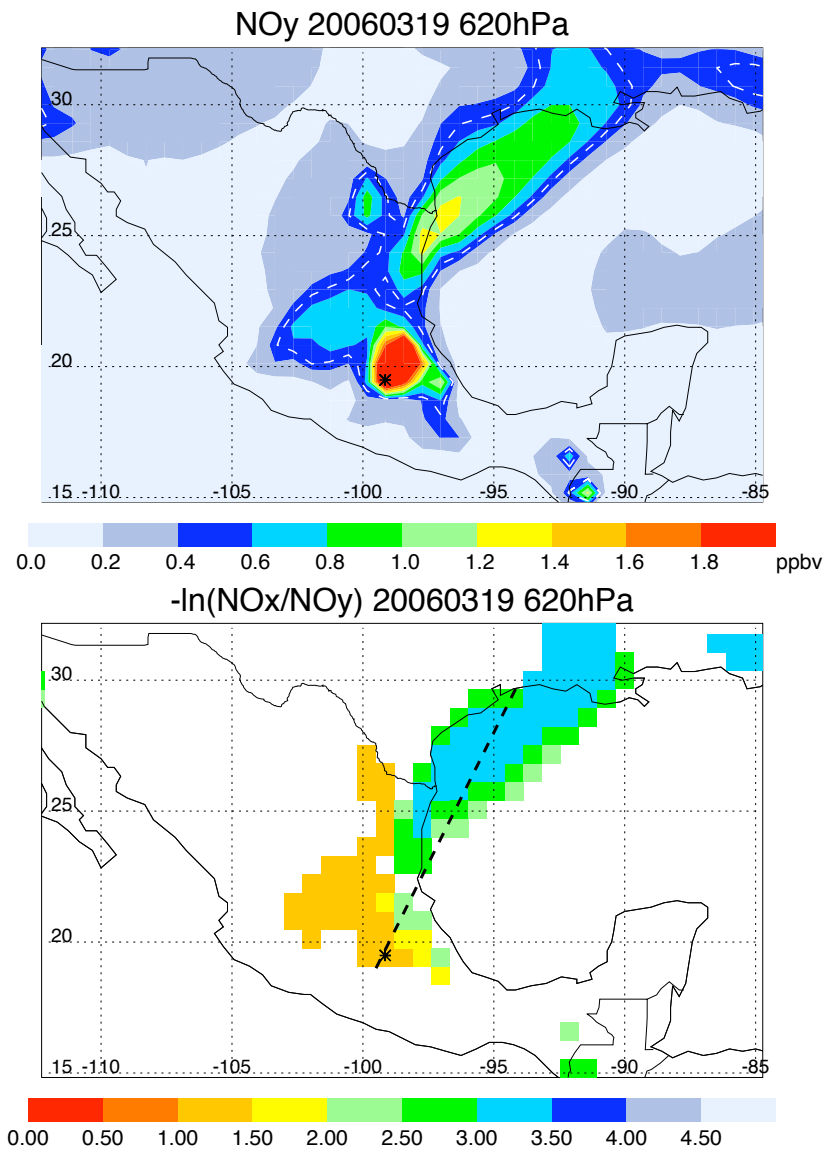

Fig. 11. $\mathrm{NO}_{\mathrm{y}}$ distribution (top) and photochemical age represented by $-\ln \left(\mathrm{NO}_{\mathrm{x}} / \mathrm{NO}_{\mathrm{y}}\right)$ (bottom) on $19 \mathrm{March}$ at $620 \mathrm{hPa}(4 \mathrm{~km})$. Asterisk indicates location of Mexico City. White dashed line in top panel indicates $0.5 \mathrm{ppbv}$ contour, which is the lower limit for values shown in bottom panel. Black dashed line from Fig. 7 is included for reference in bottom panel.

city with a mean age less than 1 day, the majority of the $\mathrm{CO}$ was emitted within 1 day. However, at higher latitudes where the plume mean age is gradually increasing from 1 to 3 days, there is an increasing contribution from pollution that is 3 to 6 days old. Thus, it is clear that a single mean age of an airmass may not be a useful parameter for the interpretation of its composition and thus the entire distribution should be considered for this purpose.

While estimation of the photochemical age using the ratio $\mathrm{NO}_{\mathrm{x}} / \mathrm{NO}_{\mathrm{y}}$ is appropriate in some cases, it can also be difficult to interpret. Among the complications is the decomposition of components of $\mathrm{NO}_{\mathrm{y}}$, in particular PAN, back to $\mathrm{NO}_{\mathrm{x}}$, which result in an apparent "rejuvenation" of the $\mathrm{NO}_{\mathrm{y}}$ in the airmass. Another major component of $\mathrm{NO}_{\mathrm{y}}, \mathrm{HNO}_{3}$, can be lost during transport due to washout, or to the uptake on dust (Querol et al., 2008; Zheng et al., 2008). In order to compare physical and photochemical ages, MOZART-4 results of $\mathrm{NO}_{\mathrm{x}}$ and $\mathrm{NO}_{\mathrm{y}}$ for the 19 March plume have been used to cal-
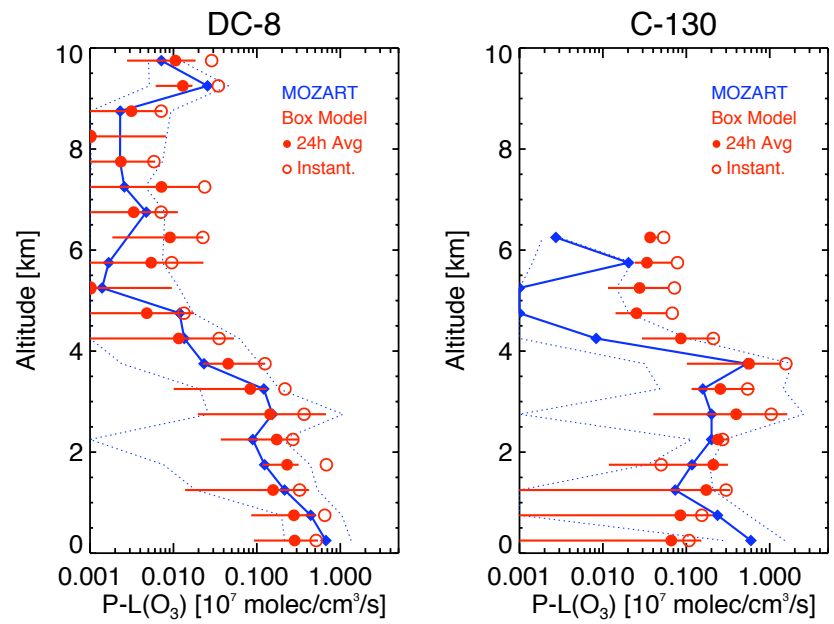

Fig. 12. Comparison of ozone net production rates from MOZART (in blue) and the NASA box model (in red), binned by altitude, for the DC-8 flights (left) and C-130 flights (right). Points indicate median values, red error bars and blue dashed lines indicate range of quartiles for box model and MOZART, respectively.

culate the photochemical age, $-\ln \left(\mathrm{NO}_{\mathrm{x}} / \mathrm{NO}_{\mathrm{y}}\right)$. These results are shown in Fig. 11, with the $\mathrm{NO}_{\mathrm{y}}$ distribution (top panel) clearly indicating strong outflow from Mexico City along the Northern Mexico and Texas Gulf coast. The $\mathrm{NO}_{\mathrm{x}} / \mathrm{NO}_{\mathrm{y}}$ ratio, however, does not show quite as clear a picture as the tagged $\mathrm{CO}$. Values are plotted only for $\mathrm{NO}_{\mathrm{y}}$ mixing ratios above $0.5 \mathrm{ppbv}$ (indicated by the white dashed line in the top panel). The fresh emissions over Mexico City are apparent with $-\ln \left(\mathrm{NO}_{\mathrm{x}} / \mathrm{NO}_{\mathrm{y}}\right)$ values of less than 1 . However, there is also a large region in Central Mexico (NW of Mexico City) with photochemical age of 1-1.5 that corresponds to relatively low $\mathrm{NO}_{\mathrm{y}}$ mixing ratios and 5-6 day physical ages (in Fig. 10). This region of low photochemical ages could be a result of relatively fresh emissions from sources outside Mexico City, but is more likely a result of loss of $\mathrm{NO}_{\mathrm{y}}$ due to washout or uptake on dust in fairly aged air.

\section{Evaluation of ozone production}

The ozone net production (production minus loss) rates from MOZART-4 are compared to box model calculations constrained by observations in Fig. 12. Results from the "constrained" version of the NASA Langley photochemical box model (Olson et al., 2006) have been used for the comparisons here, where the calculations have been constrained to the aircraft observations of NMHCs, acetone, $\mathrm{MEK}$, methanol and ethanol, in addition to $\mathrm{CO}, \mathrm{NO}, \mathrm{O}_{3}$, $\mathrm{H}_{2} \mathrm{O}, \mathrm{H}_{2} \mathrm{O}_{2}, \mathrm{CH}_{3} \mathrm{OOH}, \mathrm{HNO}_{3}$ and PAN. The box model is expected to more accurately reproduce true ozone production rates due to both its constraint to the observations, as well as its more detailed chemical mechanism. Both the instantaneous and diurnal average ozone production rates are shown, 
binned by altitude. The MOZART-4 ozone production rates have been interpolated to the DC-8 and C-130 flight tracks, and then binned by altitude. The MOZART- 4 results are interpolated from 3-h average output. However, the MOZART4 results are generally at or below the box model diurnal average production rates. The coarse resolution of the model results in lower peak values of $\mathrm{NO}_{\mathrm{x}}$ and $\mathrm{VOC}$ concentrations than observed, which in turn is likely one of the primary reasons for the underestimate of ozone production. Better agreement is seen for the DC-8 flights than the C-130, indicative that MOZART-4 reproduces the free troposphere well, where the majority of the DC- 8 flights sampled and where the spatial gradients in $\mathrm{NO}_{\mathrm{x}}$ and VOCs change much more slowly. The C-130 flights sampled the city air and urban outflow with much greater frequency, a region where MOZART4 had greater difficulty capturing the high concentrations due to the coarse model resolution.

The ozone production efficiency (OPE) of $\mathrm{NO}_{\mathrm{x}}$ is defined as the total odd oxygen $\mathrm{O}_{\mathrm{x}}\left(\mathrm{O}_{3}+\mathrm{NO}_{2}\right)$ produced per $\mathrm{NO}_{\mathrm{x}}$ oxidized. It is typically inferred from the the correlation between $\mathrm{O}_{\mathrm{x}}$ and $\mathrm{NO}_{\mathrm{z}}\left(\mathrm{NO}_{\mathrm{y}}-\mathrm{NO}_{\mathrm{x}}\right)$. The OPE has been determined for several MILAGRO data sets (Shon et al., 2008; Wood et al., 2009; Nunnermacker et al., 2008). Analysis of the C-130 measurements by Shon et al. (2008) showed low OPE (4-5) for airmasses with fresh emissions from biomass burning and urban sources, while higher efficiencies (6-9) were seen in the free troposphere. Similar values were deduced from the DOE G-1 aircraft observations (Nunnermacker et al., 2008). As shown in Sect. 5, the Mexico City region can be a complex mixture of airmasses with different photochemical ages and histories. This can make interpretation of the OPE difficult (Wood et al., 2009; Liang and Jacobson, 2000). However, as one measure of the model performance we compare the ozone production efficiency determined from MOZART-4 results with that from the aircraft observations.

Figure 13 shows this correlation for the C-130 observations and the MOZART-4 results interpolated to the C-130 flight tracks. Only the flights that included simultaneous measurements of $\mathrm{O}_{3}, \mathrm{NO}_{\mathrm{x}}$ and $\mathrm{NO}_{\mathrm{y}}$ are used, and only points where $\mathrm{NO}_{\mathrm{y}}$ is between 2 and $6 \mathrm{ppbv}$ are used, so as to filter out fresh plumes and very aged air, and keep only moderately fresh airmasses. The OPE $\left(\Delta\left[\mathrm{O}_{\mathrm{x}}\right] / \Delta\left[\mathrm{NO}_{\mathrm{Z}}\right]\right)$ inferred from the $\mathrm{C}-130$ measurements is $5.9 \pm 0.3$, while for MOZART-4 it is $9.1 \pm 0.3$. These plots show considerable scatter, but the degree of scatter is comparable for both the aircraft observations and the model, i.e., in both cases there is a range of about $20 \mathrm{ppbv}$ in $\mathrm{O}_{\mathrm{x}}$ for a given value of $\mathrm{NO}_{\mathrm{z}}$. It is not surprising that the MOZART-4 OPE is slightly higher, as the large model grid will dilute urban emissions towards a regime where ozone production is larger (e.g., Shon et al., 2008).

Another key component of predicting ozone is the concentration of VOCs, and one way to evaluate this is through the comparison of $\mathrm{OH}$ reactivity determined from observations
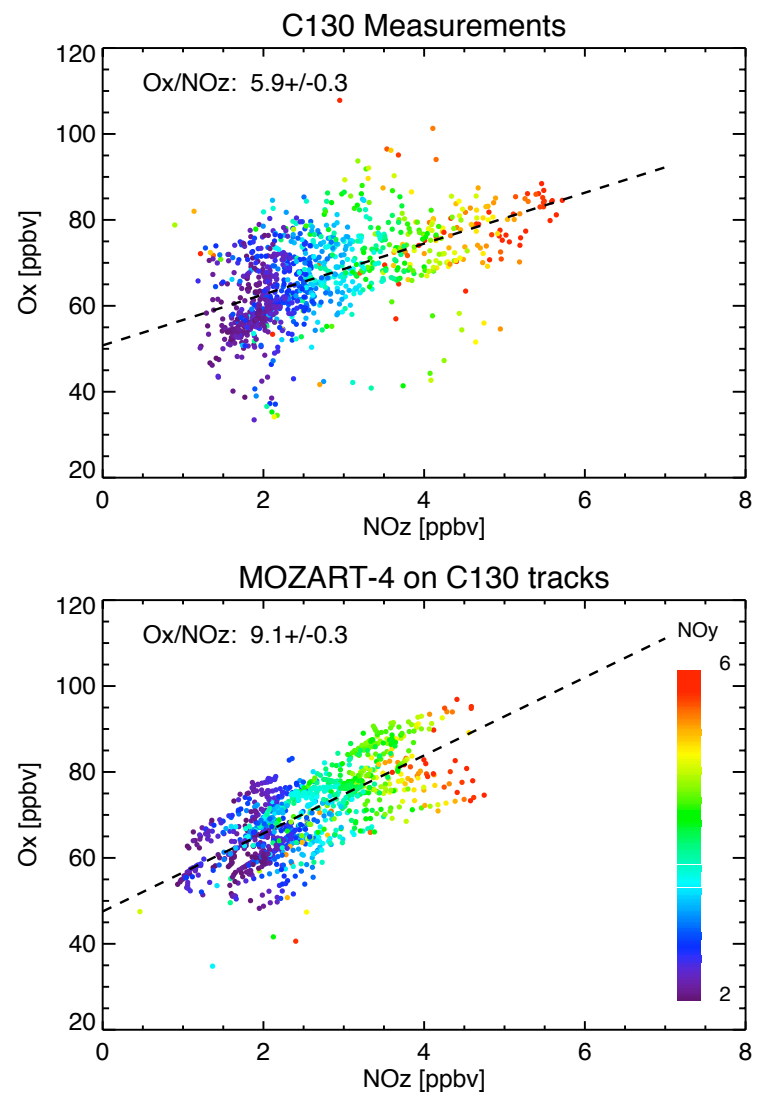

Fig. 13. Ozone production efficiency, $\mathrm{O}_{\mathrm{x}}\left(\mathrm{O}_{3}+\mathrm{NO}_{2}\right)$ vs. $\mathrm{NO}_{\mathrm{z}}$ $\left(\mathrm{NO}_{\mathrm{y}}-\mathrm{NO}_{\mathrm{x}}\right)$ from $\mathrm{C}-130$ measurements (top) and MOZART results (bottom), with points colored by $\mathrm{NO}_{y}$. The slope and its uncertainty from the linear regression of $\mathrm{O}_{\mathrm{x}}$ to $\mathrm{NO}_{\mathrm{Z}}$ is given.

with that from the model. $\mathrm{OH}$ reactivity can be calculated by summing over each VOC species, the product of its concentration by its rate constant with $\mathrm{OH}$. Figure 14 compares the $\mathrm{OH}$ reactivity calculated from the $\mathrm{C}-130$ observations with the MOZART-4 results along the flight tracks. The OH reactivity has been summed for all NMHCs and OVOCs separately and then binned by distance from Mexico City. The total MOZART-4 OH reactivity somewhat overestimates the observed reactivity and has a slightly higher NMHC contribution, which is consistent with the overestimate of the lumped alkane BIGALK shown in Fig. 4. Both the observations and MOZART-4 results show that OVOCs are an increasingly important contribution to the $\mathrm{OH}$ reactivity downwind of Mexico City and therefore a source for maintaining ozone production away from the emissions sources, as discussed in greater detail in Apel et al. (2010). Plots of MOZART-4 results for the strong outflow event of March 19 are given in Apel et al. (2010), illustrating the evolution of NMHC versus OVOC $\mathrm{OH}$ reactivity in the plume. 


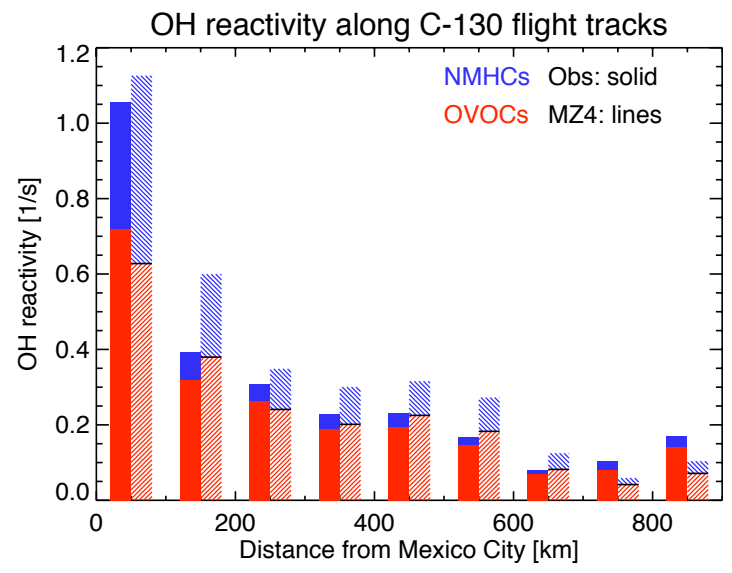

Fig. 14. OH reactivity calculated separately for NMHCs (blue) and OVOCs (red) from observations (solid fill) and MOZART (line fill) results along the $\mathrm{C}-130$ flight tracks and binned by distance from Mexico City.

\section{Ozone produced from Mexico City}

The impact of Mexico City emissions is clearly evident in the monthly average of predicted tropospheric ozone shown in Fig. 15 (top panel). As was seen in the CO distributions (Fig. 7), the air to the south and west of Mexico is relatively clean, while ozone average mixing ratios over the US are substantially higher. The amount of ozone produced from emissions in and around Mexico City can be quantified by "tagging" the NO emissions, as described by Lamarque et al. (2005) and Pfister et al. (2006, 2008b). The tagged NO (from the emissions shown in Fig. 8, top right panel) is traced through all the odd nitrogen species (e.g., $\mathrm{PAN}, \mathrm{HNO}_{3}$, organic nitrates) to account for recycling of $\mathrm{NO}_{\mathrm{x}}$. The photolysis of $\mathrm{NO}_{2}$ produces the tagged $\mathrm{O}_{3}$, which is destroyed at the same rate as the full ozone. This tagging technique is additive: if each $\mathrm{NO}_{\mathrm{x}}$ source is tagged separately, the sum of the resulting tagged $\mathrm{O}_{3}$ is equal (within a few percent) to the tagged $\mathrm{O}_{3}$ from the total $\mathrm{NO}_{\mathrm{x}}$ emissions.

The bottom panel of Fig. 15 shows the monthly tropospheric column average of ozone produced from Mexico City region emissions. Directly over Mexico City, the average column is over $25 \mathrm{ppbv}$, almost half of the total ozone at that point (about $55 \mathrm{ppbv}$ ). However, the influence of Mexico City is quickly diluted as air gets transported primarily in the southwesterly and northeasterly direction. At the TexasMexico border, Mexico City ozone is less than 7 ppbv, or about $15 \%$ of the total ozone.

There was extensive evidence that emissions from open fires around the city had a strong influence on the regional air quality during MILAGRO, especially aloft and over larger spatial scales (Yokelson et al., 2007; Crounse et al., 2009; Karl et al., 2009). Based on the CO emissions inventories and model CO tags shown in Fig. 8, fires do not seem to be a dominant contribution to the $\mathrm{CO}$ distributions and the frac-
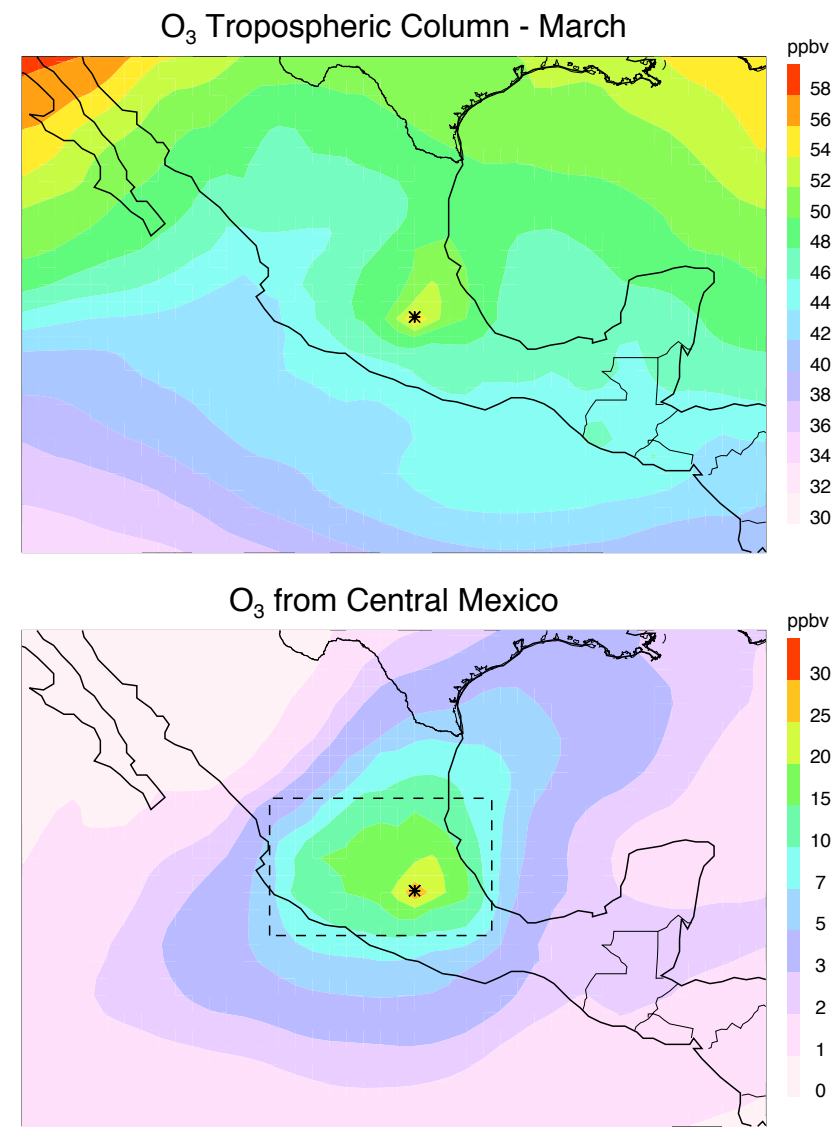

Fig. 15. Tropospheric column (surface to $6 \mathrm{~km}$ a.s.1.) of total ozone (top) and ozone produced from the Central Mexico region emissions (bottom), averaged over March 2006. The dashed box shows the region of tagged emissions shown in Fig. 8.

tional contribution of the fires to $\mathrm{NO}_{\mathrm{x}}$ is smaller than for $\mathrm{CO}$. To quantify the impact of fires on the ozone distributions, the NO emissions from fires in the Mexico City metropolitan area have been tagged, and the results are shown in the right panels of Fig. 16, with the ozone from all Central Mexico sources in the left panels. On 20 March there was a shift in the weather patterns and a rainy period significantly reduced the fire activity around the city (Fast et al., 2007). Therefore, these two time periods have been averaged separately, shown in the top and bottom panels of Fig. 16, and clearly show lower ozone amounts during the second period. Before 20 March, the contribution of ozone from fires was 3-7 ppbv over a large region of Central Mexico, but was substantially reduced for the last 10 days of March, to 1-3 ppbv.

\section{Conclusions}

MOZART-4 has been run at relatively high horizontal resolution $(70 \mathrm{~km})$ and has been shown to reproduce well many of the observations during the MILAGRO experiments in 
Central Mex $\mathrm{O}_{3}$ Mar 7-20

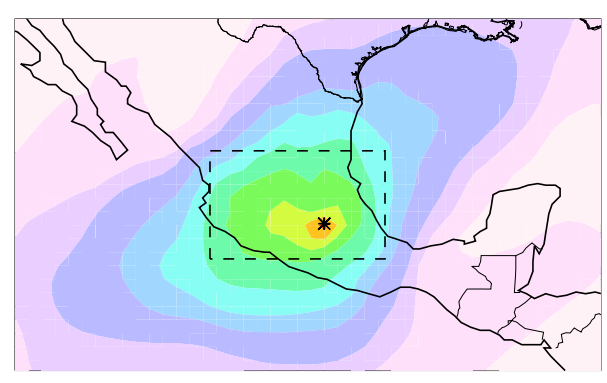

Central Mex $\mathrm{O}_{3}$ Mar 21-31

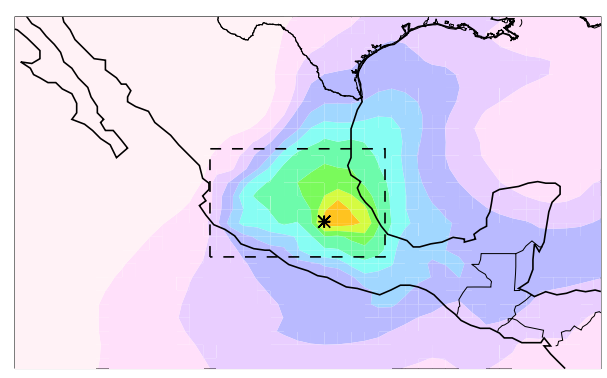

Central Mex Fire $\mathrm{O}_{3}$ Mar 7-20

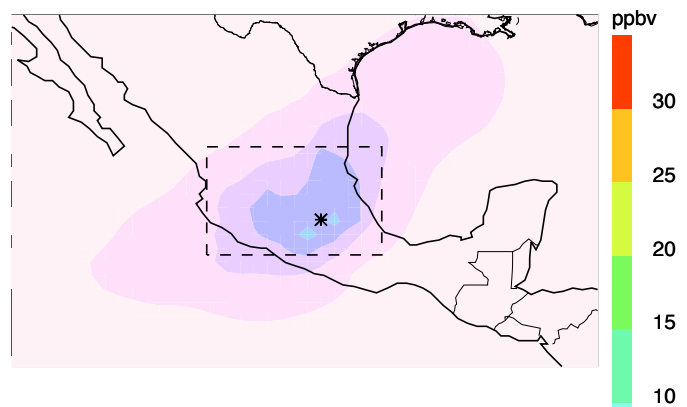

Central Mex Fire $\mathrm{O}_{3}$ Mar 21-31

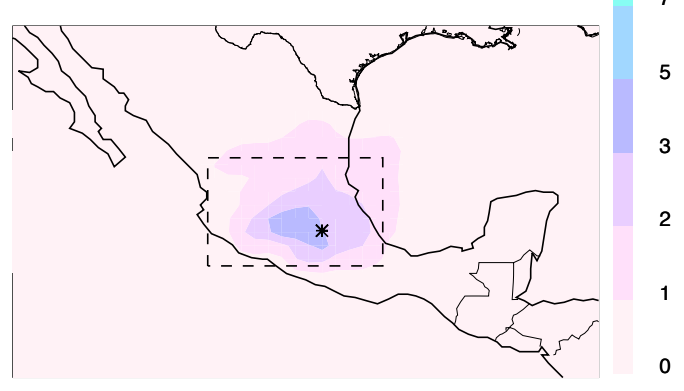

Fig. 16. Ozone from all Mexico City region emissions (left), and from open fires (right) in the Central Mexico region, before (top) and after (bottom) the rainy period. The dashed boxes show the region of tagged emissions.

Mexico during March 2006. Many of the discrepancies are likely due to errors in the emissions inventories, such as discrepancies in the speciation of VOCs, and the overestimation of black carbon from fires. The coarse horizontal resolution of the model compared to the small scale of the pollution and fire sources also contributes to model errors. The contribution of Mexico City pollution to the regional atmospheric composition was estimated for $\mathrm{CO}$ using tagged $\mathrm{CO}$ tracers. By tagging $\mathrm{CO}$ emissions in Mexico City for each day, a physical age of air, as well as the age spectrum, can be determined for any point in the region of Mexico. The age spectra show that the atmospheric composition around Mexico City is generally composed of air with a range of ages, therefore the mean photochemical age may not be an appropriate representation of a given air parcel. Even in the strong plume of Mexico City pollution carried towards Texas on 19 March, a significant fraction of air older than 2 days was present in the plume. The ozone production rate in MOZART-4 shows generally good agreement with box model simulations that have been constrained by the aircraft observations. However, the ozone production efficiency (correlation between $\mathrm{O}_{\mathrm{x}}$ and $\mathrm{NO}_{\mathrm{Z}}$ ) determined from MOZART-4 results is considerably higher than that inferred from observations, probably due primarily to the coarse model resolution diluting the $\mathrm{NO}_{\mathrm{x}}$ concentrations. $\mathrm{OH}$ reactivity calculated from the MOZART4 results somewhat overestimates the NMHC reactivity, but shows the same increasing importance of OVOCs downwind from the city, as shown by the observations. These results highlight the need for understanding the chemical evolution of pollution outflow to properly assess the impact of megacities such as Mexico City on the regional atmospheric composition.

By keeping track of the ozone produced from the NO emissions in the Central Mexico region, the contribution of Mexico City pollution on the regional tropospheric ozone column has been estimated. Directly over the city the contribution is about half, but drops quickly away from the city as the pollution is diluted by the clean tropical airmasses from the southwest of Mexico. The ozone produced by fires in Central Mexico is found to be a small contribution to the regional ozone.

Mexico City has a number of unique characteristics, such as its location in a basin surrounded by volcanoes and at high altitude, that make it difficult to generalize the findings of this study to other megacities. Cities in a more or less advanced state of development have very different relative source sector contributions, resulting in very different contributions of ozone precursors (e.g., Butler et al., 2008). These differences include the types of transportation, domestic heating and cooking, industry and power generation, all leading to unique mixes of $\mathrm{NO}_{\mathrm{x}}, \mathrm{CO}$ and VOC emissions for each city.

Acknowledgements. The authors gratefully acknowledge all of the efforts of the Science Teams of the MILAGRO experiments in producing the comprehensive data sets of atmospheric composition in and around Mexico City. The helpful and thorough comments of two anonymous reviewers are greatly appreciated. This material is 
based upon work supported by the National Aeronautics and Space Administration under Contract No. NNG06GB27G issued by the Tropospheric Chemistry Program. PFD and JLJ were supported by NSF ATM-0449815 and NOAA NA08OAR4310565. The National Center for Atmospheric Research is sponsored by the National Science Foundation.

Edited by: L. Molina

\section{References}

Andres, R. and Kasgnoc, A.: A time-averaged inventory of subaerial volcanic sulfur emissions, J. Geophys. Res., 103, 2525125261, 1998.

Aiken, A. C., DeCarlo, P. F., Kroll, J. H., Worsnop, D. R., Huffman, J. A., Docherty, K. S., Ulbrich, I. M., Mohr, C., Kimmel, J. R., Sueper, D., Sun, Y., Zhang, Q., Trimborn, A., Northway, M., Ziemann, P. J., Canagaratna, M. R., Onasch, T. B., Alfarra, M. R., Prevot, A. S. H., Dommen, J., Duplissy, J., Metzger, A., Baltensperger, U., and Jimenez, J. L.: O/C and OM/OC ratios of primary, secondary, and ambient organic aerosols with high-resolution time-of-flight aerosol mass spectrometry, Environ. Sci. Technol., 42, 4478-4485, 2008.

Aiken, A. C., Salcedo, D., Cubison, M. J., Huffman, J. A., DeCarlo, P. F., Ulbrich, I. M., Docherty, K. S., Sueper, D., Kimmel, J. R., Worsnop, D. R., Trimborn, A., Northway, M., Stone, E. A., Schauer, J. J., Volkamer, R. M., Fortner, E., de Foy, B., Wang, J., Laskin, A., Shutthanandan, V., Zheng, J., Zhang, R., Gaffney, J., Marley, N. A., Paredes-Miranda, G., Arnott, W. P., Molina, L. T., Sosa, G., and Jimenez, J. L.: Mexico City aerosol analysis during MILAGRO using high resolution aerosol mass spectrometry at the urban supersite (T0) - Part 1: Fine particle composition and organic source apportionment, Atmos. Chem. Phys., 9, 66336653, doi:10.5194/acp-9-6633-2009, 2009.

Aiken, A. C., de Foy, B., Wiedinmyer, C., DeCarlo, P. F., Ulbrich, I. M., Wehrli, M. N., Szidat, S., Prevot, A. S. H., Noda, J., Wacker, L., Volkamer, R., Fortner, E., Wang, J., Laskin, A., Shutthanandan, V., Zheng, J., Zhang, R., Paredes-Miranda, G., Arnott, W. P., Molina, L. T., Sosa, G., Querol, X., and Jimenez, J. L.: Mexico city aerosol analysis during MILAGRO using high resolution aerosol mass spectrometry at the urban supersite (T0) - Part 2: Analysis of the biomass burning contribution and the non-fossil carbon fraction, Atmos. Chem. Phys., 10, 5315-5341, doi:10.5194/acp-10-5315-2010, 2010.

Andreae, M. and Merlet, P.: Emission of trace gases and aerosols from biomass burning, Global Biogeochem. Cycles, 15, 966995, 2001.

Apel, E. C., Emmons, L. K., Karl, T., Flocke, F., Hills, A. J., Madronich, S., Lee-Taylor, J., Fried, A., Weibring, P., Walega, J., Richter, D., Tie, X., Mauldin, L., Campos, T., Weinheimer, A., Knapp, D., Sive, B., Kleinman, L., Springston, S., Zaveri, R., Ortega, J., Voss, P., Blake, D., Baker, A., Warneke, C., Welsh-Bon, D., de Gouw, J., Zheng, J., Zhang, R., Rudolph, J., Junkermann, W., and Riemer, D. D.: Chemical evolution of volatile organic compounds in the outflow of the Mexico City Metropolitan area, Atmos. Chem. Phys., 10, 2353-2375, doi:10.5194/acp-10-23532010, 2010.

Bond, T., Streets, D. G., Yarber, K. F., Nelson, S. M., Woo, J.H., and Klimont, Z.: A technology-based global inventory of black and organic carbon emissions from combustion, J. Geophys. Res., 109, D14203, doi:10.1029/2003JD003697, 2004.

Butler, T.M., Lawrence, M.G., Gurjar, B.R., van Aardenne, J., Schultz, M. and Lelieveld, J.: The representation of emissions from megacities in global emission inventories, Atmos. Environ., 42, 703-719, 2008.

Crounse, J. D., DeCarlo, P. F., Blake, D. R., Emmons, L. K., Campos, T. L., Apel, E. C., Clarke, A. D., Weinheimer, A. J., McCabe, D. C., Yokelson, R. J., Jimenez, J. L., and Wennberg, P. O.: Biomass burning and urban air pollution over the Central Mexican Plateau, Atmos. Chem. Phys., 9, 4929-4944, doi:10.5194/acp-9-4929-2009, 2009.

de Foy, B., Fast, J. D., Paech, S. J., Phillips, D., Walters, J. T., Coulter, R. L., Martin, T. J., Pekour, M. S., Shaw, W. J., Kastendeuch, P. P., Marley, N. A., Retama, A., and Molina, L. T.: Basinscale wind transport during the MILAGRO field campaign and comparison to climatology using cluster analysis, Atmos. Chem. Phys., 8, 1209-1224, doi:10.5194/acp-8-1209-2008, 2008.

de Gouw, J. and Jimenez, J.: Organic Aerosols in the Earths Atmosphere, Environ. Sci. Technol., 43, 7614-7618, doi:10.1021/es9006004, 2009.

de Gouw, J. A., Welsh-Bon, D., Warneke, C., Kuster, W. C., Alexander, L., Baker, A. K., Beyersdorf, A. J., Blake, D. R., Canagaratna, M., Celada, A. T., Huey, L. G., Junkermann, W., Onasch, T. B., Salcido, A., Sjostedt, S. J., Sullivan, A. P., Tanner, D. J., Vargas, O., Weber, R. J., Worsnop, D. R., Yu, X. Y., and Zaveri, R.: Emission and chemistry of organic carbon in the gas and aerosol phase at a sub-urban site near Mexico City in March 2006 during the MILAGRO study, Atmos. Chem. Phys., 9, 3425-3442, doi:10.5194/acp-9-3425-2009, 2009.

DeCarlo, P., Kimmel, J., Trimborn, A., Northway, M., Jayne, J., Aiken, A., Gonin, M., Fuhrer, K., Horvath, T., Docherty, K., Worsnop, D., and Jimenez, J.: Field-deployable, high-resolution, time-of-flight aerosol mass spectrometer, Anal. Chem., 78, 8281-8289, 2006.

DeCarlo, P. F., Dunlea, E. J., Kimmel, J. R., Aiken, A. C., Sueper, D., Crounse, J., Wennberg, P. O., Emmons, L., Shinozuka, Y., Clarke, A., Zhou, J., Tomlinson, J., Collins, D. R., Knapp, D., Weinheimer, A. J., Montzka, D. D., Campos, T., and Jimenez, J. L.: Fast airborne aerosol size and chemistry measurements above Mexico City and Central Mexico during the MILAGRO campaign, Atmos. Chem. Phys., 8, 4027-4048, doi:10.5194/acp8-4027-2008, 2008.

Dunlea, E. J., DeCarlo, P. F., Aiken, A. C., Kimmel, J. R., Peltier, R. E., Weber, R. J., Tomlinson, J., Collins, D. R., Shinozuka, Y., McNaughton, C. S., Howell, S. G., Clarke, A. D., Emmons, L. K., Apel, E. C., Pfister, G. G., van Donkelaar, A., Martin, R. V., Millet, D. B., Heald, C. L., and Jimenez, J. L.: Evolution of Asian aerosols during transpacific transport in INTEX-B, Atmos. Chem. Phys., 9, 7257-7287, doi:10.5194/acp-9-7257-2009, 2009.

Dzepina, K., Volkamer, R. M., Madronich, S., Tulet, P., Ulbrich, I. M., Zhang, Q., Cappa, C. D., Ziemann, P. J., and Jimenez, J. L.: Evaluation of recently-proposed secondary organic aerosol models for a case study in Mexico City, Atmos. Chem. Phys., 9, 5681-5709, doi:10.5194/acp-9-5681-2009, 2009.

Edgerton, S., Bian, X., Doran, J., Fast, J., et al.: Particulate air pollution in Mexico City: a collaborative research project, J. Air Waste Manage., 49, 1221-1229, 1999. 
Emmons, L. K., Walters, S., Hess, P. G., Lamarque, J.-F., Pfister, G. G., Fillmore, D., Granier, C., Guenther, A., Kinnison, D., Laepple, T., Orlando, J., Tie, X., Tyndall, G., Wiedinmyer, C., Baughcum, S. L., and Kloster, S.: Description and evaluation of the Model for Ozone and Related chemical Tracers, version 4 (MOZART-4), Geosci. Model Dev., 3, 43-67, 2010.

Fast, J., Aiken, A. C., Allan, J., Alexander, L., Campos, T., Canagaratna, M. R., Chapman, E., DeCarlo, P. F., de Foy, B., Gaffney, J., de Gouw, J., Doran, J. C., Emmons, L., Hodzic, A., Herndon, S. C., Huey, G., Jayne, J. T., Jimenez, J. L., Kleinman, L., Kuster, W., Marley, N., Russell, L., Ochoa, C., Onasch, T. B., Pekour, M., Song, C., Ulbrich, I. M., Warneke, C., WelshBon, D., Wiedinmyer, C., Worsnop, D. R., Yu, X.-Y., and Zaveri, R.: Evaluating simulated primary anthropogenic and biomass burning organic aerosols during MILAGRO: implications for assessing treatments of secondary organic aerosols, Atmos. Chem. Phys., 9, 6191-6215, doi:10.5194/acp-9-6191-2009, 2009.

Fast, J. D., de Foy, B., Acevedo Rosas, F., Caetano, E., Carmichael, G., Emmons, L., McKenna, D., Mena, M., Skamarock, W., Tie, X., Coulter, R. L., Barnard, J. C., Wiedinmyer, C., and Madronich, S.: A meteorological overview of the MILAGRO field campaigns, Atmos. Chem. Phys., 7, 2233-2257, doi:10.5194/acp-7-2233-2007, 2007.

Gerbig, C., Schmitgen, S., Kley, D., Volz-Thomas, A., Dewey, K., and Haaks, D.: An improved fast-response vacuum-UV resonance fluorescence CO instrument, J. Geophys. Res., 104, 16991704, 1999.

Granier, C., Guenther, A., Lamarque, J., Mieville, A., Muller, J., Olivier, J., Orlando, J., Peters, J., Petron, G., Tyndall, G., and Wallens, S.: Present and future surface emissions of atmospheric compounds, European Commission report EVK 2199900011, http://www.aero.jussieu.fr/projet/ACCENT/POET.php, 2004.

Grutter, M., Basaldud, R., Rivera, C., Harig, R., Junkerman, W., Caetano, E., and Delgado-Granados, $\mathrm{H}$.: $\mathrm{SO}_{2}$ emissions from Popocatépetl volcano: emission rates and plume imaging using optical remote sensing techniques, Atmos. Chem. Phys., 8, 6655-6663, doi:10.5194/acp-8-6655-2008, 2008.

Guenther, A., Karl, T., Harley, P., Wiedinmyer, C., Palmer, P. I., and Geron, C.: Estimates of global terrestrial isoprene emissions using MEGAN (Model of Emissions of Gases and Aerosols from Nature), Atmos. Chem. Phys., 6, 3181-3210, doi:10.5194/acp-63181-2006, 2006.

Hallquist, M., Wenger, J. C., Baltensperger, U., Rudich, Y., Simpson, D., Claeys, M., Dommen, J., Donahue, N. M., George, C., Goldstein, A. H., Hamilton, J. F., Herrmann, H., Hoffmann, T., Iinuma, Y., Jang, M., Jenkin, M. E., Jimenez, J. L., Kiendler-Scharr, A., Maenhaut, W., McFiggans, G., Mentel, Th. F., Monod, A., Prévôt, A. S. H., Seinfeld, J. H., Surratt, J. D., Szmigielski, R., and Wildt, J.: The formation, properties and impact of secondary organic aerosol: current and emerging issues, Atmos. Chem. Phys., 9, 5155-5236, doi:10.5194/acp-95155-2009, 2009.

Heald, C. L., Jacob, D. J., Park, R. J., Russell, L. M., Huebert, B. J., Seinfeld, J. H., Liao, H., and Weber, R. J.: A large organic aerosol source in the free troposphere missing from current models, Geophys. Res. Lett., 32, L18809, doi:10.1029/2005GL023831, 2005.

Hodzic, A., Jimenez, J. L., Madronich, S., Aiken, A. C., Bessagnet, B., Curci, G., Fast, J., Lamarque, J.-F., Onasch, T. B., Roux,
G., Schauer, J. J., Stone, E. A., and Ulbrich, I. M.: Modeling organic aerosols during MILAGRO: importance of biogenic secondary organic aerosols, Atmos. Chem. Phys., 9, 6949-6981, doi:10.5194/acp-9-6949-2009, 2009.

Kanamitsu, M., Alpert, J., Campana, K., Caplan, P., Deaven, D., Iredell, M., Katz, B., Pan, H.-L., Sela, J., and White, G.: Recent changes implemented into the global forecast system at NMC, Weather Forecast., 6, 425-435, 1991.

Karl, T., Apel, E., Hodzic, A., Riemer, D. D., Blake, D. R., and Wiedinmyer, C.: Emissions of volatile organic compounds inferred from airborne flux measurements over a megacity, Atmos. Chem. Phys., 9, 271-285, doi:10.5194/acp-9-271-2009, 2009.

Kleinman, L. I., Springston, S. R., Daum, P. H., Lee, Y.-N., Nunnermacker, L. J., Senum, G. I., Wang, J., Weinstein-Lloyd, J., Alexander, M. L., Hubbe, J., Ortega, J., Canagaratna, M. R., and Jayne, J.: The time evolution of aerosol composition over the Mexico City plateau, Atmos. Chem. Phys., 8, 1559-1575, doi:10.5194/acp-8-1559-2008, 2008.

Lamarque, J.-F., Hess, P., Emmons, L., Buja, L., Washington, W., and Granier, C.: Tropospheric ozone evolution between 1890 and 1990, J. Geophys. Res., 110, D08304, doi:10.1029/2004JD005537, 2005.

Liang, J. and Jacobson, M. Z.: Effects of subgrid segregation on ozone production efficiency in a chemical model, Atmos. Environ., 34, 2975-2982, 2000.

Madronich, S. and Flocke, S.: The role of solar radiation in atmospheric chemistry, in: Handbook of Environmental Chemistry, edited by: Boule, P., Springer, Heidelberg, 1-26, 1999.

Mayer, M., Wang, C., Webster, M., and Prinn, R. G.: Linking local air pollution to global chemistry and climate, J. Geophys. Res., 105, 22869-22896, 2000.

Molina, L. T., Kolb, C. E., de Foy, B., Lamb, B. K., Brune, W. H., Jimenez, J. L., Ramos-Villegas, R., Sarmiento, J., ParamoFigueroa, V. H., Cardenas, B., Gutierrez-Avedoy, V., and Molina, M. J.: Air quality in North America's most populous city overview of the MCMA-2003 campaign, Atmos. Chem. Phys., 7, 2447-2473, doi:10.5194/acp-7-2447-2007, 2007.

Molina, L. T., Madronich, S., Gaffney, J. S., Apel, E., de Foy, B., Fast, J., Ferrare, R., Herndon, S., Jimenez, J. L., Lamb, B., Osornio-Vargas, A. R., Russell, P., Schauer, J. J., Stevens, P. S., and Zavala, M.: An overview of the MILAGRO 2006 campaign: Mexico City emissions and their transport and transformation, Atmos. Chem. Phys. Discuss., 10, 7819-7983, doi:10.5194/acpd-10-7819-2010, 2010.

Nunnermacker, L. J., Weinstein-Lloyd, J. B., Hillery, B., Giebel, B., Kleinman, L. I., Springston, S. R., Daum, P. H., Gaffney, J., Marley, N., and Huey, G.: Aircraft and ground-based measurements of hydroperoxides during the 2006 MILAGRO field campaign, Atmos. Chem. Phys., 8, 7619-7636, doi:10.5194/acp8-7619-2008, 2008.

Olivier, J. and Berdowski, J.: Global emissions sources and sinks, in: The Climate System, edited by: Berdowski, J., Guicherit, R., and Heij, B. J., A.A. Balkema Publishers/Swets, Zeitlinger Publishers, Lisse, The Netherlands, 33-78, 2001.

Olivier, J., Bouwman, A., Berdowski, J., Veldt, C., Bloos, J., Visschedijk, A., van der Maas, C., and Zandveld, P.: Sectoral emission inventories of greenhouse gases for 1990 on a per country basis as well as on 1×1 degree, Environ. Sci. Policy, 2, 241-264, 1999. 
Olivier, J., Van Aardenne, J., Dentener, F., Ganzeveld, L., and Peters, J.: Recent trends in global greenhouse gas emissions: regional trends and spatial distribution of key sources, in: Non$\mathrm{CO}_{2}$ Greenhouse Gases (NCGG-4), edited by: van Amstel, A. (coord.), Millpress, Rotterdam, 325-330, 2005.

Olson, J. R., Crawford, J. H., Chen, G., Brune, W. H., Faloona, I. C., Tan, D., Harder, H., and Martinez, M.: A reevaluation of airborne $\mathrm{HO}_{\mathrm{x}}$ observations from NASA field campaigns, J. Geophys. Res., 111, D10301, doi:10.1029/2005JD006617, 2006.

Pfister, G. G., Emmons, L. K., Hess, P. G., Honrath, R. et al.: Ozone production from the 2004 North American boreal fires, J. Geophys. Res., 111, D24S07, doi:10.1029/2006JD007695, 2006.

Pfister, G. G., Emmons, L. K., Hess, P. G., Lamarque, J.-F., Thompson, A. M., and Yorks, J. E.: Analysis of the summer 2004 ozone budget over the United States using Intercontinental Transport Experiment Ozonesonde Network Study (IONS) observations and Model of Ozone and Related Tracers (MOZART-4) simulations, J. Geophys. Res., 113, D23306, doi:10.1029/2008JD010190, 2008b.

Querol, X., Pey, J., Minguillón, M. C., Pérez, N., Alastuey, A., Viana, M., Moreno, T., Bernabé, R. M., Blanco, S., Cárdenas, B., Vega, E., Sosa, G., Escalona, S., Ruiz, H., and Artíñano, B.: PM speciation and sources in Mexico during the MILAGRO-2006 Campaign, Atmos. Chem. Phys., 8, 111-128, doi:10.5194/acp8-111-2008, 2008.

Sachse, G. W., Hill, G. F., Wade, L. O., and Perry, M. G.: Fastresponse, high-precision carbon monoxide sensor using a tunable diode laser absorption technique, J. Geophys. Res., 92, 20712081, 1987.

Shetter, R. and Müller, M.: Photolysis frequency measurements using actinic flux spectroradiometry during the PEM-Tropics mission: instrumentation description and some results, J. Geophys. Res., 104, 5647-5661, 1999.

Shon, Z.-H., Madronich, S., Song, S.-K., Flocke, F. M., Knapp, D. J., Anderson, R. S., Shetter, R. E., Cantrell, C. A., Hall, S. R., and Tie, X.: Characteristics of the $\mathrm{NO}-\mathrm{NO}_{2}-\mathrm{O}_{3}$ system in different chemical regimes during the MIRAGE-Mex field campaign, Atmos. Chem. Phys., 8, 7153-7164, doi:10.5194/acp-8-7153-2008, 2008.

Singh, H. B., Brune, W. H., Crawford, J. H., Flocke, F., and Jacob, D. J.: Chemistry and transport of pollution over the Gulf of Mexico and the Pacific: spring 2006 INTEX-B campaign overview and first results, Atmos. Chem. Phys., 9, 2301-2318, doi:10.5194/acp-9-2301-2009, 2009.

Stone, E. A., Snyder, D. C., Sheesley, R. J., Sullivan, A. P., Weber, R. J., and Schauer, J. J.: Source apportionment of fine organic aerosol in Mexico City during the MILAGRO experiment 2006, Atmos. Chem. Phys., 8, 1249-1259, doi:10.5194/acp-81249-2008, 2008.

Tsimpidi, A. P., Karydis, V. A., Zavala, M., Lei, W., Molina, L., Ulbrich, I. M., Jimenez, J. L., and Pandis, S. N.: Evaluation of the volatility basis-set approach for the simulation of organic aerosol formation in the Mexico City metropolitan area, Atmos. Chem. Phys., 10, 525-546, doi:10.5194/acp-10-525-2010, 2010.

van der Werf, G. R., Randerson, J. T., Giglio, L., Collatz, G. J., Kasibhatla, P. S., and Arellano Jr., A. F.: Interannual variability in global biomass burning emissions from 1997 to 2004, Atmos. Chem. Phys., 6, 3423-3441, doi:10.5194/acp-6-3423-2006, 2006.
Vay, S. A., Tyler, S. C., Choi, Y., Blake, D. R., Blake, N. J., Sachse, G. W., Diskin, G. S., and Singh, H. B.: Sources and transport of $\Delta^{14} \mathrm{C}$ in $\mathrm{CO}_{2}$ within the Mexico City Basin and vicinity, Atmos. Chem. Phys., 9, 4973-4985, doi:10.5194/acp-9-4973-2009, 2009.

Velasco, E., Lamb, B., Westberg, H., Allwine, E., Sosa, G., ArriagaColina, J. L., Jobson, B. T., Alexander, M. L., Prazeller, P., Knighton, W. B., Rogers, T. M., Grutter, M., Herndon, S. C., Kolb, C. E., Zavala, M., de Foy, B., Volkamer, R., Molina, L. T., and Molina, M. J.: Distribution, magnitudes, reactivities, ratios and diurnal patterns of volatile organic compounds in the Valley of Mexico during the MCMA 2002 \& 2003 field campaigns, Atmos. Chem. Phys., 7, 329-353, doi:10.5194/acp-7-329-2007, 2007.

Velasco, E., Pressley, S., Grivicke, R., Allwine, E., Coons, T., Foster, W., Jobson, B. T., Westberg, H., Ramos, R., Hernández, F., Molina, L. T., and Lamb, B.: Eddy covariance flux measurements of pollutant gases in urban Mexico City, Atmos. Chem. Phys., 9, 7325-7342, doi:10.5194/acp-9-7325-2009, 2009.

Volkamer, R., Jimenez, J., San Martini, F., Dzepina, K., Zhang, Q., D. Salcedo, Molina, L., Worsnop, D., and Molina, M.: Secondary organic aerosol formation from anthropogenic air pollution: rapid and higher than expected, Geophys. Res. Lett., 33, L17811, doi:10.1029/2006GL026899, 2006.

Walega, J., Dye, J., Grahek, F., and Ridley, B.: A compact measurement system for the simultaneous determination of $\mathrm{NO}, \mathrm{NO}_{2}$, $\mathrm{NO}_{\mathrm{y}}$, and $\mathrm{O}_{3}$ using a small aircraft, Proc. SPIE, 1443, 232-241, doi:10.1117/12.46167, 1991.

Warneke, C., McKeen, S., de Gouw, J., et al.: Determination of urban volatile organic compound emission ratios and comparison with an emissions database, J. Geophys. Res., 112, D10S47, doi:10.1029/2006JD007930, 2007.

Wiedinmyer, C., Quayle, B., Geron, C., Belote, A., McKenzie, D., Zhang, X., O'Neill, S., and Wynne, K.: Estimating emissions from fires in North America for air quality modeling, Atmos. Environ., 40, 3419-3432, 2006.

Wood, E. C., Herndon, S. C., Onasch, T. B., Kroll, J. H., Canagaratna, M. R., Kolb, C. E., Worsnop, D. R., Neuman, J. A., Seila, R., Zavala, M., and Knighton, W. B.: A case study of ozone production, nitrogen oxides, and the radical budget in Mexico City, Atmos. Chem. Phys., 9, 2499-2516, doi:10.5194/acp-9-2499-2009, 2009.

Yokelson, R. J., Urbanski, S. P., Atlas, E. L., Toohey, D. W., Alvarado, E. C., Crounse, J. D., Wennberg, P. O., Fisher, M. E., Wold, C. E., Campos, T. L., Adachi, K., Buseck, P. R., and Hao, W. M.: Emissions from forest fires near Mexico City, Atmos. Chem. Phys., 7, 5569-5584, doi:10.5194/acp-7-5569-2007, 2007.

Zhang, Q., Streets, D. G., Carmichael, G. R., He, K. B., Huo, H., Kannari, A., Klimont, Z., Park, I. S., Reddy, S., Fu, J. S., Chen, D., Duan, L., Lei, Y., Wang, L. T., and Yao, Z. L.: Asian emissions in 2006 for the NASA INTEX-B mission, Atmos. Chem. Phys., 9, 5131-5153, doi:10.5194/acp-9-5131-2009, 2009.

Zheng, J., Zhang, R., Fortner, E. C., Volkamer, R. M., Molina, L., Aiken, A. C., Jimenez, J. L., Gaeggeler, K., Dommen, J., Dusanter, S., Stevens, P. S., and Tie, X.: Measurements of $\mathrm{HNO}_{3}$ and $\mathrm{N}_{2} \mathrm{O}_{5}$ using ion drift-chemical ionization mass spectrometry during the MILAGRO/MCMA-2006 campaign, Atmos. Chem. Phys., 8, 6823-6838, doi:10.5194/acp-8-6823-2008, 2008. 